\title{
Plant systematics and differentiation of species over trans-Beringian land connections including a newly recognized cupressaceous conifer Ditaxocladus Guo \& Sun
}

\author{
VAlEntin A. Krassilov, TAtiana M. KodRul \& NATAlia P. Maslova
}

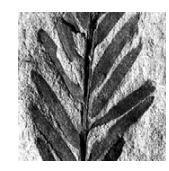

\begin{abstract}
Rich paleobotanical localities of eastern Asia and western North America provide ample opportunities for documentation and analysis of trans-Beringian migration and differentiation. Species-level comparisons are made for cupressaceous conifers Mesocyparis and Ditaxocladus, as well as for the platanoid genera Macginitiea and Platimeliphyllum. Asiatic and American species (forms) of these genera are interpreted as representing successive speciation events en route from northeastern Asia to North America (Mesocyparis rosanovii - M. beringiana - M. borealis and Platimeliphyllum valentinii-P. palanense-Platimeliphyllum sp. from Fushun and Clarno) or, alternatively, a divergent speciation over the trans-Beringian ranges, as in Ditaxocladus. A new species of cupressaceous conifer from the Paleocene of Amur Province is recognized: Ditaxocladus kivdensis sp. nov. The dominant latest Cretaceous-Paleocene group of trochodendrocarpoids (Trochodendroides type leaves, Trochodendrocarpus, Joffrea and Alasia reproductive structures) shows a generic-level differentiation across Beringia attesting to periodic rather than permanent floristic connections. The aquatic/semiaquatic congeners had appeared on both sides of the bridge with the rise of floating plant biomass in the mid-Cretaceous, then synchronously entering the Late Cretaceous (Quereuxia) and terminal Cretaceous (Limnobiophyllum, Cobbania) stages. The trans-Beringian continuity of aquatic vegetation might have been sustained by dinosaur migrations. Cobbania was lost to the end-Cretaceous extinction, but trochodendrocarpoids culminated at the boundary attesting to a widespread temperization of global climates. - Key words: trans-Beringian migrations, speciation, conifers, angiosperms, aquatic plants, climate change, Cretaceous, Paleocene.
\end{abstract}

\begin{abstract}
Krassilov, V.A., Kodrul, T.M. \& MASlova, N.P. 2010. Plant systematics and differentiation of species over trans-Beringian land connections including a newly recognized cupressaceous conifer Ditaxocladus Guo \& Sun. Bulletin of Geosciences 85(1), 95-110 (11 figures). Czech Geological Survey, Prague. ISSN 1214-1119. Manuscript received May 24, 2009; accepted in revised form October 5, 2009; published online January 8, 2010; issued March 22, 2010.

Valentin A. Krassilov (corresponding and communicating author), Paleontological Institute, Russian Academy of Sciences (RAS), Profsoyuznaya 123, Moscow, 117997 Russia; vakrassilov@ gmail.com; Institute of Evolution, University of Haifa, Mt Carmel, Haifa 31905; krassilo@ research.haifa.ac.il•Tatiana M. Kodrul, Geological Institute, (RAS), Pyzhevskii per. 7, Moscow, 119017 Russia; tkodrul@gmail.ru• Natalia P. Maslova, Paleontological Institute, (RAS), Profsoyuznaya 123, Moscow, 117997 Russia; paleobotany_ns@yahoo.com
\end{abstract}

Trans-Beringian floristic connections through geological times have been considered since late nineteenth century. Nevertheless, the potentias of paleobotanical data has been scarcely realised so far regarding the role of periodically emerging land bridges in resolving such lingering problems in plant evolution and phytogeography as migration and differentiation of plant species and plant communities. Similar floristic elements are recorded in the western North American and Asian fossil plant localities since the Permian at least, but their taxonomic relatedness and the pathways of their transPacific distribution remain debatable on account of alternative possibilities, such as homeomorphy, parallel developments, or circumventive pathways across the North Atlantic
Tulean Bridge. Capacities of the Bering Land Bridge as an intercontinental migration pathway must have been affected by tectonic activities, sea level and climate change. Paleofloristic comparisons across the Bering Strait are relevant to all these.

The traditional approach of listing shared generic names suggests a high probability of permanent or at least episodic trans-Beringian floristic connections through geological times. Now is the time for exploring the problem a little deeper by using the strictly defined and taxonomically distinctive plant genera, as well as the species level comparisons, for revealing potential exchanges and the patterns of speciation over the vast territories connected by the Bering Land Bridge. 


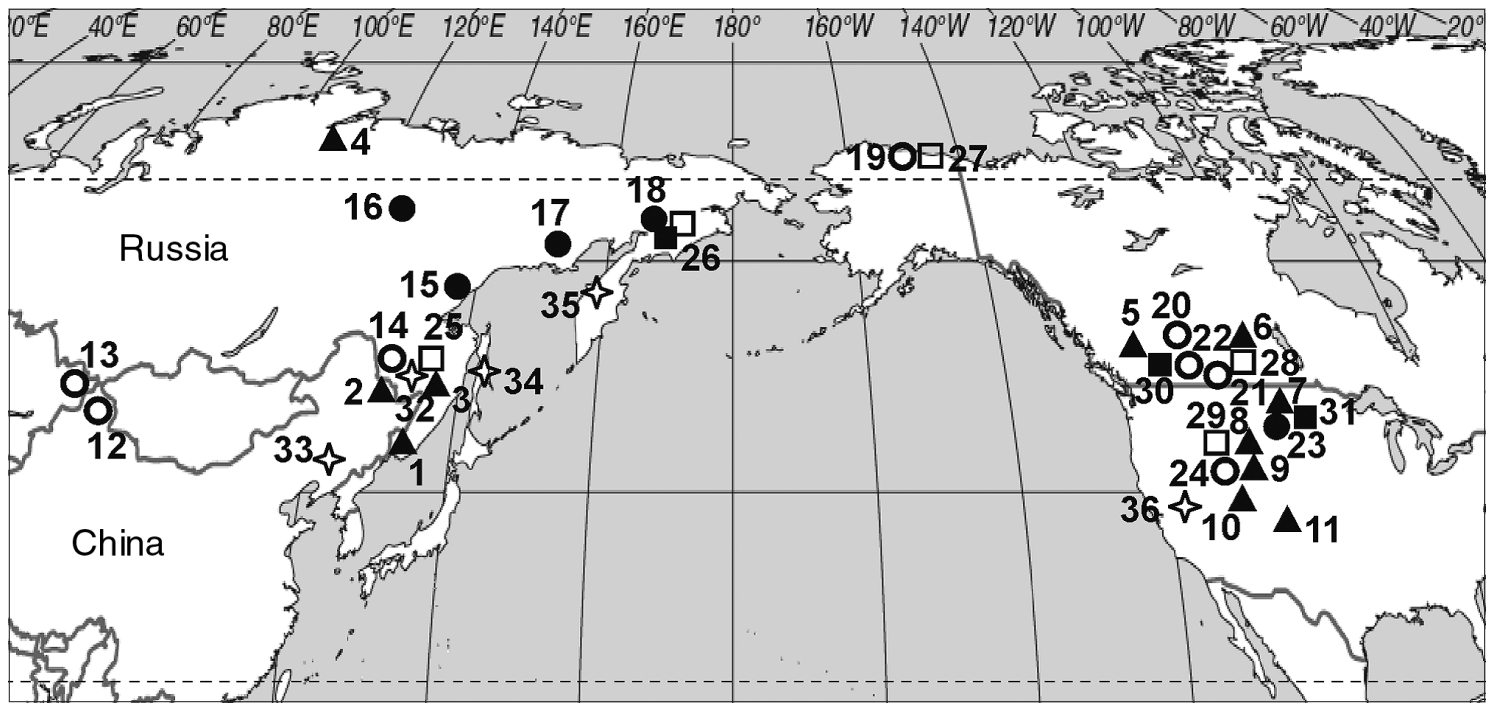

Figure 1. Map showing Cretaceous (black characters) and Paleogene (white characters) localities for some plant taxa with Asian and North American distribution: Cobbania (1-11, triangles), Ditaxocladus (12-24, circles), Mesocyparis (25-31, squares), and Platimeliphyllum (32-36, asterisks). 1: Alchan River, Primorye, Cenomanian (Bugdaeva et al. 2006), 2: Jiayin, Heilongjiang, Campanian (Sun et al. 2007), 3: Kundur, Amur Province, Campanian (Markevich et al. 2005), 4: Khatanga River, Campanian (Abramova 1983, Golovneva, 2005), 5: Dinosaur Park, Alberta, Campanian (Stockey et al. 2007), 6: Southern Saskatchewan, Maastrichtian (Berry 1935) and Campanian (Dorf 1942, Bell 1949), 7: Slope and Bowman counties, North Dakota, Late Maastrichtian (Johnson 2002), 8: Park County, Wyoming, Late Campanian (Stockey et al. 2007), 9: Converse and Weston counties, Wyoming, Late Maastrichtian (Dorf 1942), 10: Grand County, Utah, Middle Campanian (Stockey 2007), 11: San Juan Basin, New Mexico, Middle Campanian (Knowlton 1917), 12: Altai, Xinjiang, Paleocene (Guo et al. 1984), 13: Zhuvankara, Zaissan Basin, Kazakhstan, Paleocene (Romanova 1975), 14: Mount Belaya vicinity, Amur Region, Paleocene (Kryshtofovich \& Baikovskaya 1966, Krassilov 1976), 15: Gyrbykan River, Cenomanian (Lebedev 1987), 16: Viljui River, Turonian-Coniacian (Sveshnikova 1967), 17: Arkagala River, Coniacian (Samylina 1988), 18: Bol'shaja Ajanka River, Campanian (Lebedev 1987), 19: Sagwon Bluffs, Alaska, Paleocene (Herman et al. 2009), 20: Genesee, Alberta, Paleocene (Chandrasekharam 1974), 21: Ravenscrag Butte, Saskatchewan, Paleocene (McIver \& Basinger 1990, 1993), 22: Tongue Creek, Alberta, Paleocene (McIver 1992), 23: Bowman County, North Dakota, Maastrichtian (Johnson 2002), 24: Bighorn Basin, Wyoming, Paleocene (Johnson 1985), 25: Arkhara-Boguchan, Amur Province, Paleocene (Kodrul et al. 2006), 26: Koryak Upland, Maastrichtian, Paleocene (Golovneva 1994), 27: Sagwon Bluffs, Alaska, Paleocene (Herman et al. 2009), 28: Ravenscrag Butte, Saskatchewan, Paleocene (McIver \& Basinger 1987), 29: Wyoming, Paleocene (McIver \& Basinger 1987), 30: Drumheller region, Alberta, Maastrichtian (McIver \& Aulenback 1994), 31: Missouri River Valley, North Dakota, Maastrichtian (Peppe et al. 2007), 32: Arkhara-Boguchan, Amur Province, Paleocene (Kodrul \& Maslova 2007), 33: Fushun, Jilin, Eocene, 34: Sakhalin Island, Eocene (Maslova 2002), 35: Western Kamchatka, Paleocene, Eocene (Maslova 2002), 36: Clarno, Oregon, Eocene (S. Manchester, personal communication).

The continuity of the late Cretaceous and Paleocene floras of northeastern Asia and western North America, with a number of shared species, has been recognized by many researchers on both sides of the Bering Strait (Kryshtofovich 1935, Wolfe 1975, Hsü 1983, Tiffney 1985, Tiffney \& Manchester 2001, Manchester et al. 2009). The plant localities of these ages represent mixed conifer-broadleaved vegetation, with taxodiaceous and cupressaceous conifers, trochodendrocarpoids and platanoids as dominant elements. Numerically conspicuous are remains of aquatic plants and these also seemed to have been taxonomically related across Beringia. The floristic developments seem continuous through geological time as well. Owing to the recent advances in fossil plant taxonomy, this sketchy picture is now laid open for further scrutiny.

\section{Material and methods}

The material used for trans-Beringian comparisons was collected by the authors from the Campanian-Paleocene deposits of Amur Province and from the Paleocene - Eocene deposits of Sakhalin and Kamchatka in the Russian Far East (Krassilov 1976; Bugdaeva et al. 2001; Akhmetiev et al. 2002; Markevich et al. 2005; Maslova 2002, 2003). The figured specimens came from the Mount Belaya locality on the right bank of Bureya River about $12 \mathrm{~km}$ from the mouth $\left(49^{\circ} 36^{\prime} 06.6^{\prime \prime} \mathrm{N}, 129^{\circ} 36^{\prime} 05.2^{\prime \prime} \mathrm{E}\right.$, WGS $84)$, the Kundur locality along Chita-Khabarovsk federal road between Udurchukan and Mutnaya Rivers near Kundur railway station $\left(49^{\circ} 03^{\prime} 44.6^{\prime \prime} \mathrm{N}, 130^{\circ} 55^{\prime} 19.5^{\prime \prime} \mathrm{E}\right)$, and Progress (49 $\left.42^{\prime} 23.6^{\prime \prime} \mathrm{N}, 129^{\circ} 37^{\prime} 28.0^{\prime \prime} \mathrm{E}\right)$ and Pioneer coal quarries $\left(49^{\circ} 39^{\prime} 13.7^{\prime \prime} \mathrm{N}, 1^{\circ} 9^{\circ} 33^{\prime} 47.0^{\prime \prime} \mathrm{E}\right.$; $49^{\circ} 40^{\prime} 53.9^{\prime \prime} \mathrm{N}, 129^{\circ} 34^{\prime} 00.1^{\prime \prime}$ E) near Raichikhinsk, as well as the Arkhara-Boguchan Quarry $15 \mathrm{~km}$ southeast of Arkhara $\left(49^{\circ} 18^{\prime} 45.1^{\prime \prime} \mathrm{N}, 130^{\circ} 12^{\prime} 45.4^{\prime \prime} \mathrm{E}\right.$; ? $49^{\circ} 18^{\prime} 52.3^{\prime \prime} \mathrm{N}$, $130^{\circ} 12^{\prime} 42.7^{\prime \prime} \mathrm{E}$; $\left.49^{\circ} 18^{\prime} 59.2^{\prime \prime} \mathrm{N}, 130^{\circ} 12^{\prime} 44.5^{\prime \prime} \mathrm{E}\right)$. Specimens of Alasia pojarkovae (Krassilov) Golovneva from the Paleocene of Amur Province were obtained on loan courtesy of Lina Golovneva. Extant Fokienia Henry \& Thomas was examined in the Fairy Lake Botanical Garden, Shenzhen, China. Material of extant Cercidiphyllum japo- 
Figure 2. Mesocyparis rosanovii Kodrul, Tekleva \& Krassilov (cupressaceous conifer) from the $\mathrm{Pa}$ leocene of Amur Province, Russia. - A - alternate vegetative branches and fertile zones of opposite seed cones arranged in a decussate order. GIN 4867 No. AB1-141. • B, C - microstrobili, SEM. GIN 4867, No. AB1-101, No. AB1-141. • D - microsporophyll with five sporangia, abaxial view. GIN, No. AB1-374. - E - pollen grains, SEM. GIN 4867 No. AB1-101. • F - shoot with opposite branching. GIN 4867 No. AB1-169. • G - shoot with a terminal microstrobilus. GIN 4867 No. AB1-276. $\bullet \mathrm{H}$ - cone scale showing scars of five ovules. $\bullet$ I - fertile zone of a shoot bearing seed cones. Detail of holotype GIN 4867 No. AB1-233. - J - microsporophyll with sporangia, adaxial view, SEM. GIN 4867 No. AB1-101. Scale bars $\mathrm{A}, \mathrm{F}, \mathrm{I}=5 \mathrm{~mm} ; \mathrm{C}, \mathrm{D}=1 \mathrm{~mm} ; \mathrm{G}=$ $2 \mathrm{~mm}$. Scale bars for B, E, H, J are on the figures.
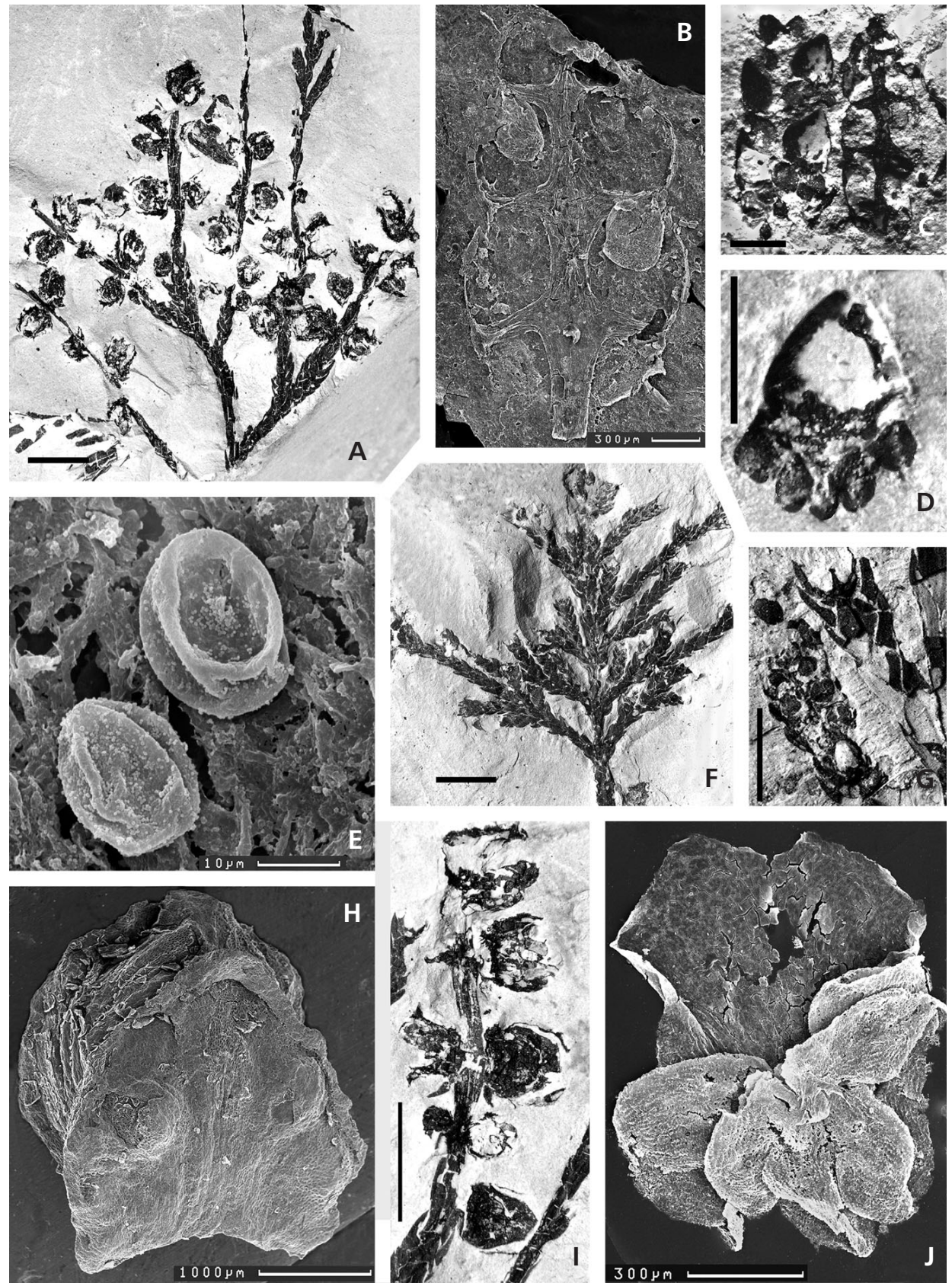

nicum Siebold \& Zuccarini was provided by the Botanical Garden of the Moscow State University.

The fossil material includes impressions and compressions of leaves and reproductive structures, the micromorphology and cuticular preparations of which were studied by means of reflected and transmitted light microscopy and scanning electron microscopy. Transfer preparations of pollen organs were used for extracting in situ pollen grains. Photographs were taken with Leica DFC 320 and Nikon Coolpix 8700 digital cameras. The materials are deposited in the Geological Institute (GIN), collection No. 4867, and Paleontological Institute (PIN), Russian Academy of Sciences.

\section{RESULTS}

\section{Cupressaceous conifers}

Fossil conifers are perhaps most suitable for the species level comparisons, because their leafy shoots are frequently anatomically well-preserved, with both pollen cones and seed cones still attached, thus providing nearly complete sets of characters, by which natural taxa are recognized in this group. One such conifer is Mesocyparis McIver \& Basinger, erected for Cupressinocladus-type vegetative shoots with decussate leaves bearing paired seed cones of 


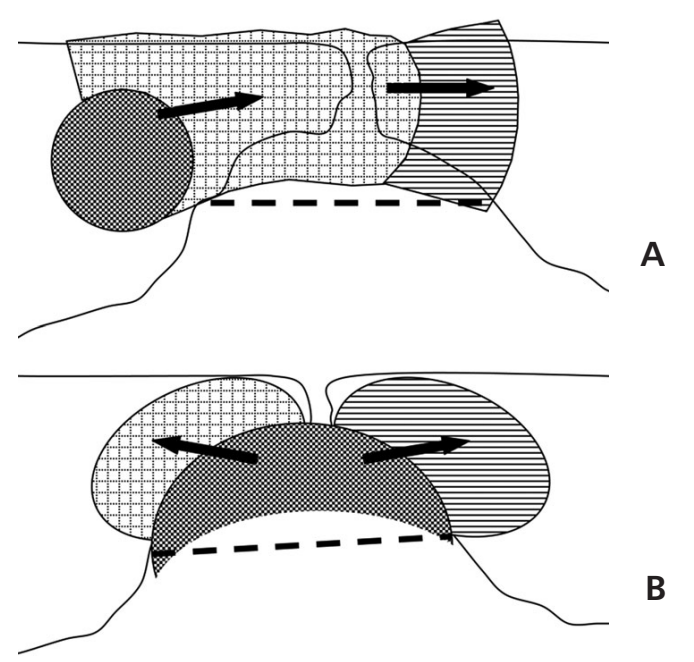

Figure 3. Schematic patterns of speciation over the trans-Beringian land connection (ancestral species range stippled, derived species ranges differently hachured). $\bullet$ A - successive derivation of species from marginal populations; as in Mesocyparis rosanovii - M. beringiana - M. borealis and Platimeliphyllum valentinii - P. palanense - P. sp. from Fushun and Clarno. - B - differentiation of isolated populations over the transBeringian range of the stem species, as in Ditaxocladus spp.

few woody scales (McIver \& Basinger 1987). The type species, M. borealis McIver \& Basinger from the Paleocene of Saskatchewan, Canada was also found in the roughly contemporaneous deposits of Wyoming, McIver $\&$ Aulenback (1994) recognized two additional species, $M$. umbonata McIver \& Aulenback from the Maastrichtian of Alberta, Canada, and M. beringiana (Golovneva) McIver \& Aulenback from the Maastrichtian-Early Paleocene of Koryak Upland, Russia. Our material from the Early Paleocene of Amur Province represents a fourth species, M. rosanovii Kodrul, Tekleva \& Krassilov (Fig. 2A-J).

Summing up the taxonomically significant characters of the four species, Mesocyparis was characterized as having terminal branchlets at the axils of each pair of lateral leaves of plagiotropous penultimate branches, dimorphic facial and lateral leaves through the branching system, both pollen and ovulate cones in fertile zones of penultimate branches, microsporophylls with leafy apophyses bearing two to several sporangia, inaperturate pollen grains, and seed cones of four fertile scales bearing two to several bilaterally winged seeds each (Kodrul et al. 2006).

All the above listed characters can be used for interspecific comparisons. Thus, $M$. rosanovii differs from its congeners in the polymorphism of the opposite and alternate branching (shared with the Maastrichtian M. umbonata, but strictly opposite in the other species), the leafy microsporophylls with stomata, a greater number of sporangia per microsporophyll (up to five versus two in the other species, approaching the maximum for the family), and the same number of ovules per seed scale. According to the widely held character polarity concept (see Takh- tajan 1991), all these categories of distinctions - polymorphism, high and unstable number of metameric organs, and photosynthetic reproductive structures - are considered primitive in seed plants. It is assumed (Kodrul et al. 2006) that $M$. rosanovi is a morphologically conservative representative of an ancestral Cretaceous group owing its transBeringian distribution to the Campanian climate warming. As the morphologically most primitive among the Paleocene species, it is considered basal for the Paleocene round of migration and speciation over the Bering Land Bridge, involving the derived forms $M$. beringiana and $M$. borealis.

The species level comparisons are presently extended to another cupressaceous genus, Ditaxocladus Guo \& Sun, previously assigned to Androvettia, Fokienia, Fokieniopsis or Libocedrus. The genus has been erected for the frond-like foliage with opposite branches from the Paleocene of Xinjiang Uygur Autonomous Region, northwestern China (Guo et al. 1984). Subsequently, attached cones were described from the type locality by Kvaček et al. (2000). The closely similar cupressaceous leafy twigs with attached seed cones and detached pollen cones were recorded from the Paleocene of Saskatchewan and Alberta, Canada as Fokienia ravenscragensis McIver \& Basinger (McIver \& Basinger 1990, McIver 1992). The assignment to the extant genus was based on similarity of seed cone structures. A new species Ditaxocladus kivdensis sp. nov. is known from three Paleocene localities in the vicinities of Raichikhinsk, the Amur Province, representing leafy shoots with cuticular structures studied on mineral films under SEM, pollen cones and seed cones.

While the generic identity of the Amurian, Chinese and North American species is beyond reasonable doubt, the specific distinctions are mostly quantitative. Thus the Amurian conifer differs from the Canadian in having denser branchlets, smaller pollen cones of fewer microsporophylls, and smaller pollen grains. The seed cones are pendulous rather than erect, smaller and oblong rather than subglobose, with the umbo more often subapical than central, as is the case in the Canadian cones (McIver \& Basinger 1990, McIver 1992). The Chinese specimens are closer to, and perhaps conspecific with, the North American conifer in having somewhat smaller globose to subglobose seed cones with rhomboid peltate scales, a central umbo, and a prominent transverse ridge (Guo et al., unpublished manuscript).

Although their species level distinctness remains uncertain, the local populations of Ditaxocladus show a considerable degree of morphological differentiation. The Amurian and Canadian populations share more character states with the Chinese ditaxoclades than between themselves. Our logical assumption, although not as yet supported by chronological evidence, is that the Chinese population is closest to the morphological grade 
Figure 4. Platanoid leaves from the Paleocene of East Asia and North America. - A - Platimeliphyllum sp. from the Eocene Clarno Formation, White Cliffs locality, Oregon, USA. UF 263-17265. - B - Platimeliphyllum valentinii Kodrul \& Maslova from the Paleocene Tsagayan Formation, Arkhara-Boguchan locality, Amur Province, Russia. Holotype GIN 4867 No. AB3-115. • C - Macginitiea latiloba Budantsev from the Paleocene-Eocene of Kamchatka. PIN No. 3736-76. • D - Platimeliphyllum palanense (Budants.) N. Maslova from the Upper Paleocene-Lower Eocene Tkaprovayam Formation, Kamchatka. PIN No. 4778-243. Scale bars $10 \mathrm{~mm}$.
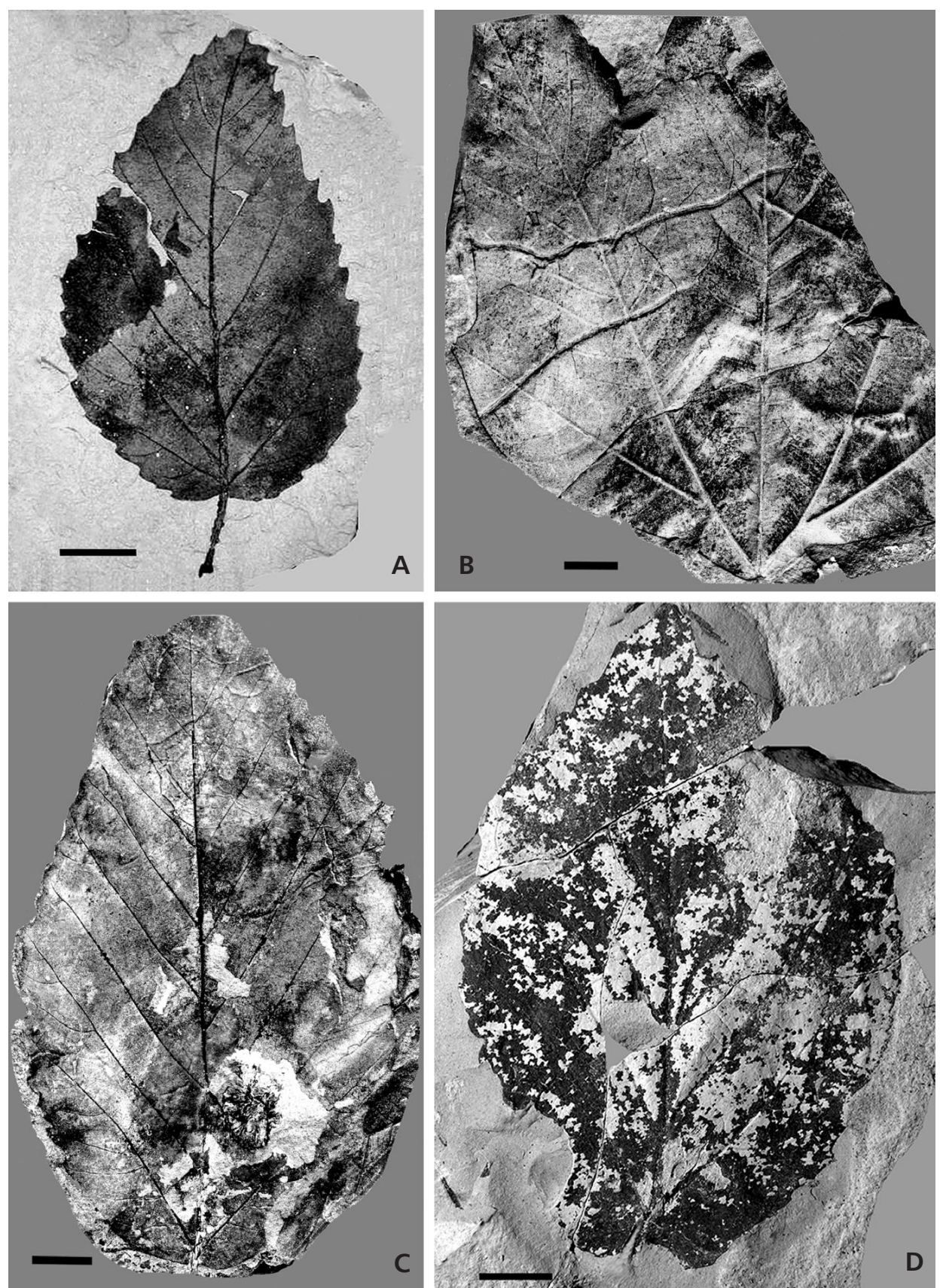

of basal ditaxoclades spreading over the Beringian Land Bridge. The Amurian and Canadian populations might have been independently derived from this grade as a result of separation of Asiatic and American species ranges (Fig. 3A, B).

\section{Platanoids}

Prominent in the Late Cretaceous and Paleogene lowlands of eastern Asia and western North America were plants with platanoid leaves assigned to extant genus Platanus, e.g.,
Platanus nobilis Newberry (Pigg \& Stockey 1991) or extinct morphogenera Macginitiea Wolfe et Wehr (leaves: Wolfe \& Wehr 1987), Platananthus Manchester (staminate heads: Manchester 1986), and Macginicarpa Manchester (pistillate heads: Manchester 1986). The distinctions between the Paleocene "Platanus" and Macginitiea fall in the range of intraspecific variations in extant plane trees, the associating reproductive structures being of the same morphotype and different from those of extant Platanus. The recent tendency is to split the leaf genera into rigorously defined morphotypes the intercontinental sharing of which can be meaningful form phytogeographical point of view. 


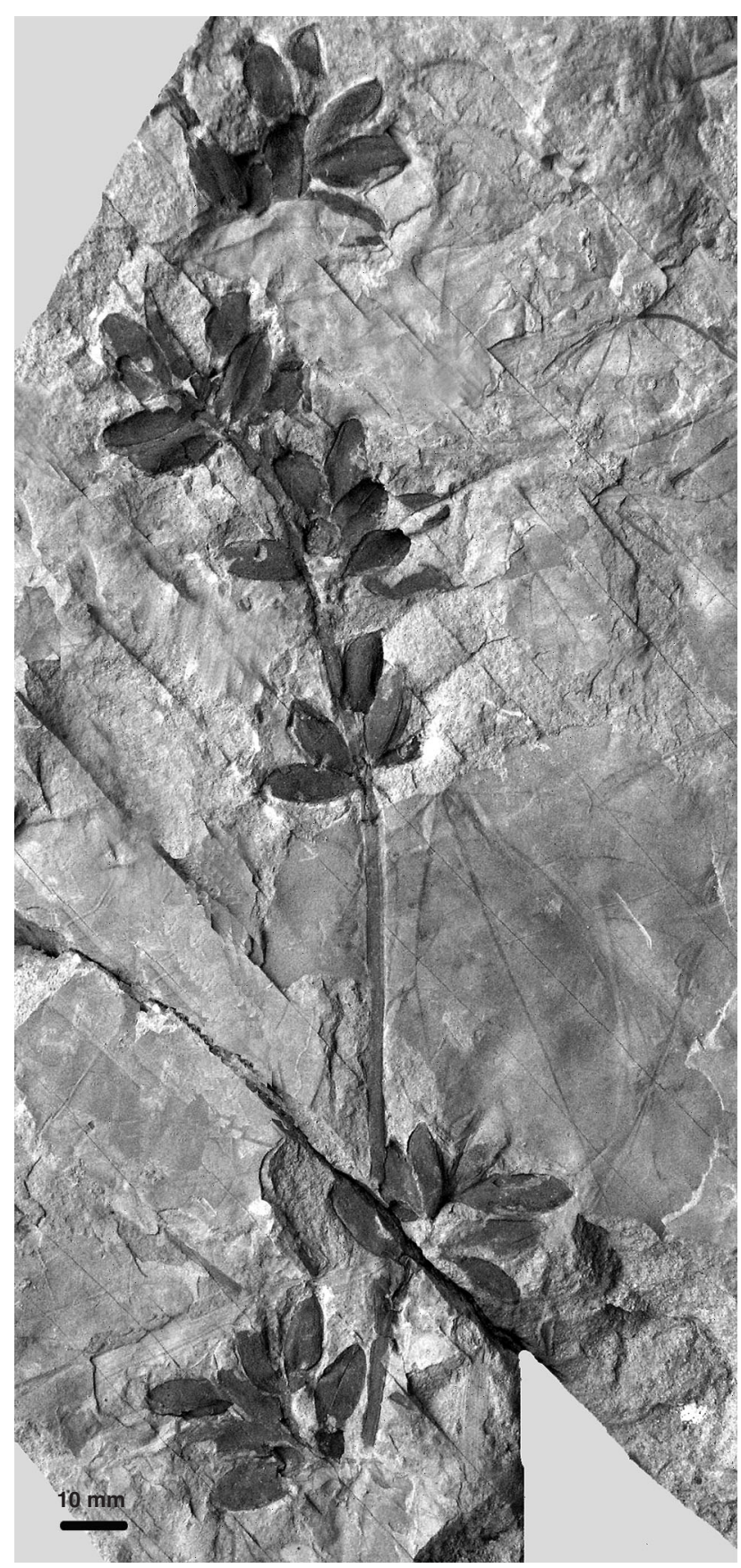

Figure 5. Trochodendrocarpus arcticus (Heer) Kryshtofovich (trochodendrocarpoids), a. paniculate infructescence with terminal raceme, Paleocene, Tsagayan Formation, White Mountain locality, Amur Province, Russia, No. 563-221. $10 \mathrm{~mm}$.

The Late Paleocene to Early Eocene Asiatic species Macginitiea latiloba Budantsev (Budantsev 1996, Maslova 2003) is practically indistinguishable from $M$. whitneyi Manchester (Manchester 1986) from the Early Eocene Chalk Bluffs Formation, California, both having shallower sinuses between leaf lobes than in the other leaf species (Fig. 4C). The broadly overlapping variation ranges of their leaf shapes and venation suggest that these forms were conspecific.

Platimeliphyllum N. Maslova combines a generalized "platanoid" aspect with a pronounced leaf blade asymmetry and camptodromous branches of the basal veins that are more typical of hamamelidaceous foliage (Fig. 4A, B, D). The only Early Paleocene representative of the genus, $P$. valentinii Kodrul \& N. Maslova (Kodrul \& Maslova 2007), is highly polymorphic, including rare leaf shape varieties that are shared with the supposedly derived Late Paleocene-Early Eocene species P. palanense (Budantsev) N. Maslova from Kamchatka (Maslova 2002), as well as in the contemporaneous species from Fushun, China, and Clarno, U.S.A. (S.R. Manchester, personal communication). Hypothetic phylogenetic relationships between these and the other Platimeliphyllum species has P. valentinii as a basal Asiatic species, with the Fushun and then Clarno platymeliphylls derived from it in the course of transBeringian migrations at about the Paleocene/Eocene boundary, a sequence comparable to that of Mesocyparis rosanovii-M. beringiana $-M$. borealis (above).

\section{Trochodendrocarpoids}

Dominant in the middle-high latitude fossil plant assemblages of eastern Asia and western North America over the Cretaceous-Paleocene transition were deciduous broadleaved plants with dimorphic leafy shoots, the leaves of which were commonly assigned to Trochodendroides Berry, but also to other genera (Krassilov 1976). Its leaf shapes, leaf margin morphology and venation patterns are highly polymorphic, and the species can be better defined by the ranges of variation than through the typological approach (Krassilov 1989).

The associated reproductive structures might have been more informative if having been less problematically interpreted. The commonly found infructescences are racemes or panicles of partly paired follicular fruits described as Nyssidium, Trochodendrocarpus or Joffrea (Fig. 5). Since Brown (1939), American paleobotanists have compared these structures to pistillate organs of extant Cercidiphyllum Siebold \& Zucc. Thus, "Cercidiphyllum-like" Joffrea Crane \& Stockey was reconstructed as having short shoots with a circle of foliage leaves and with two pistillate racemes in the middle (Crane \& Stockey 1985). Such a configuration is totally unlike Cercidiphyllum, the mostly decussate short shoots of which produce a sympodially branched system of gynoecial axis and a solitary leaf (functioning as a foliage leaf later in development), with the growing point enclosed in a pit at the base of petiole (Fig. 6A, B). No imaginable morphological transformation would link such structure to Joffrea or Trochodendrocarpus. The seeds of Cercidiphyllum, with a characteristic loop of the vascular bundle, have no more than a superficial 

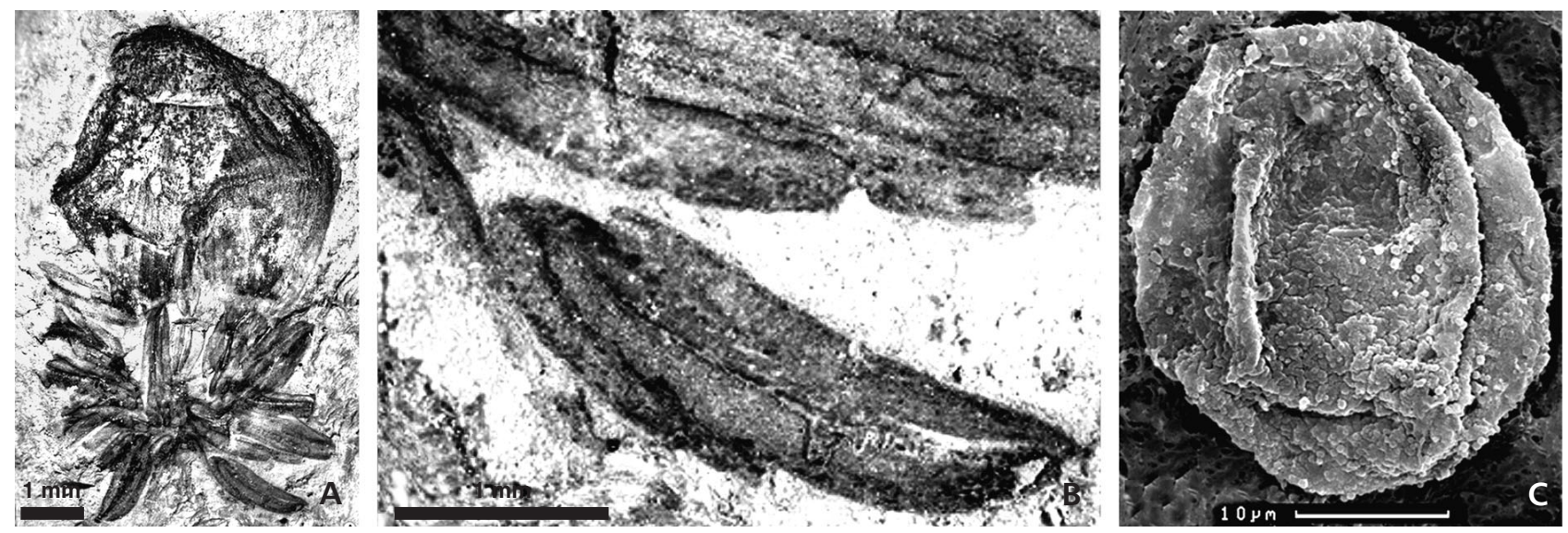

Figure 6. Alasia sp. (trochodendrocarpoids), Paleocene, Kivda bed, Tsagayan Formation, Pioneer locality, Amur Province, Russia, BIN 1537-44. -A - staminate inflorescence, distal part with one flower exserted, $\bullet$ B - stamen with a massive dorsifixed introrse anther. $\bullet$ C - in situ pollen grain, SEM.

resemblance to those of the fossil genera. Moreover, the recently found Turonian and Coniacian inflorescences (Krassilov et al. 2005, Nishida 2007) are much more Cercidiphyllum-like than the geologically younger Trochodendrocarpus - Joffrea group. The associated leaves Eocercidiphyllites are readily recognizable by prominent marginal glands as in juvenile leaves of extant Cercidiphyllum, but lacking or inconspicuous in Trochodendroides.

The staminate organs Alasia Golovneva (2006) have been also assigned to Cercidiphyllaceae, but our revision (Krassilov \& Kodrul, 2008) revealed inflorescences of helically arranged bracts subtending flowers of numerous stamens, whereas in Cercidiphyllum staminate flowers develop opposite the solitary short-shoot leaf and are subtended by a lateral pair (or sometimes also a median pair) of small bracts. In Alasia, the stamens at anthesis have short filaments (long filaments in Cercidiphyllum) and massive anthers that were dorsifixed (basifixed in Cercidiphyllum: Endress 1993), introrse (latrorse in Cercidiphyllum: Endress 1993), and lacking a prominently protruding connective. The pollen grains were tricolpate with long colpi, whereas in Cercidiphyllum the apertural type, although sometimes described as tricolpate with short colpi, is actually triporate (Figs 6B, 7A-C).

At first glance, this brief excursion into morphology of flowering plants may seem irrelevant to the theme of transBeringian species-level connections. Yet morphological interpretations may seriously affect the paleoecological and phytogeographic inferences, as in the case of American Joffrea speirsii Crane \& Stockey and Asiatic Trochodendrocarpus arcticus (Heer) Krysht., both of which have been compared to Cercidiphyllum japonicum (Crane \& Stockey 1985). The paniculate infructescences of Trochodendrocarpus, with lateral racemose paracladia and a terminal raceme (Fig. 5), were interpreted (Crane \& Stockey 1985) as long shoots bearing lateral (also terminal?) short shoots, thus minimising their distinctions from Joffrea and Cercidi- phyllum. These interpretations concealed a considerable morphological differentiation of the Asiatic and American representatives, which complies with a long history of periodic, rather than permanent, exchanges. Frequent finds of short shoots in association with Trochodendroides leaves (Crane \& Stockey 1985), might have been related to shedding leafy short shoots typical of temperate riparian trees, but not of Cercidiphyllum, in which the short shoots are reproductive, with a solitary prophyll functioning as foliage leaf at maturity and the long leafy shoots developing in the position of floral structures. These unique features indicate a quite different paleoecology of progenitorial forms.

\section{Aquatic plants}

The aquatic plant assemblages are potentially a plentiful source of shared taxa, with such prominent genera as $\mathrm{Ne}$ lumbites Berry, Quereuxia Kryshtofovich, Limnobiophyllum Krassilov, and Cobbania Stockey, Rothwell \& Johnson being represented by closely similar and probably conspecific forms in the roughly contemporaneous Cretaceous - Paleocene fossil plant localities of northeastern Asia and western North America (Berry 1911, Samylina 1968, Krassilov 1976, Hickey 2001, Johnson 2002, Upchurch et al. 2004, Stockey et al. 2007, Sun et al. 2007).

Floating plants, both ferns and angiosperms, simultaneously appeared in the Albian. Their remarkable synchronism attests to a radical change in the trophic level and vegetation structure of lacustrine ecosystems (Krassilov \& Makulbekov 1995; Krassilov \& Golovneva 1999, 2001). At this stage, Nelumbites was the most prominent floating leaf morphotype both in Asia and North America. Its affinities to extant Nelumbo are supported by both the vegetative morphology, with dimorphic floating and emergent leaves, and the associated floral remains (Upchurch et al. 1994, Krassilov et al. 2005). Later in the mid-Cretaceous, 

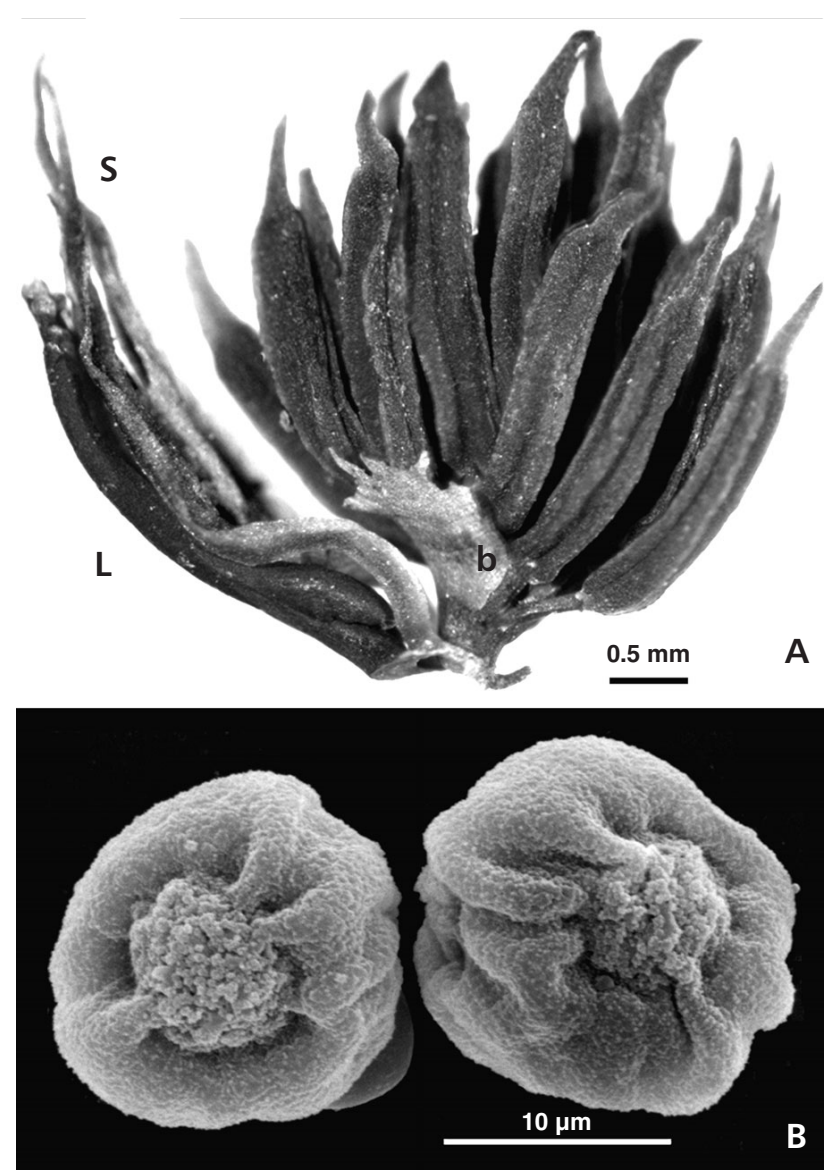

Figure 7. Extant Cercidiphyllum japonicum Siebold \& Zuccarini (Cercidiphyllaceae), Botanical Garden of Moscow State University. • A - staminate flower before anthesis, $\mathrm{L}$ - short-shoot leaf, $\mathrm{S}$ - stipule, $\mathrm{b}$ - bract. - B - triporate pollen grains, SEM.

the entries of Quereuxia and allied morphotypes, e.g. Jonquieria Krassilov (1979), mark the next stage of aquatic angiosperm evolution, roughly corresponding to the appearance of trochodendrocarpoids in the dryland vegetation. Limnobiophyllum and Cobbania, as well as Potamogeton-like and Typha-like monocots, appeared in the Campanian and culminated in the Maastrichtian-early Paleocene, representing a rich aquatic vegetation of modern aspect. The parallelism of aquatic successions in Asia and North America is perhaps the most convincing evidence of trans-Beringian land connections (Krassilov 1973, 1976; Golovneva 1987; Kvaček 1995; Golovneva 1997, 2000; Stockey 2006; Stockey et al. 1997, Stockey \& Rothwell 1997; Riley \& Stockey 2004).

As in the case of terrestrial trochodendrocarpoids, the species-level analysis is complicated by controversial morphological interpretations. The alleged differences between American Trapago and Asiatic Quereuxia involve a dichotomous branching in the latter, deduced from a photograph in Krassilov (1989), actually illustrating pseudodichotomous branching characteristic of both forms. These plants are obviously congeneric (Manchester 1999) and probably conspecific.

Genus Limnobiophyllum has been assigned to the Arales on the basis of stomatographic similarities alone (Krassilov 1973). It was emended for the whole sterile plants (Kvaček 1995) considered being intermediate between the Araceae and Lemnaceae. Unfortunately, the utility of epidermal characters for recognition of the genus was not confirmed for material outside the type locality.

The name Cobbania has been for several years used colloquially, publication of Asiatic material being postponed until formal validation of the genus (Stockey et al. 2007). The plant was assigned to the Arales, although neither cuticular nor reproductive evidence was found in the Canadian material. Seed remains found with the leaves were not studied in detail and their attribution to the same plant was not considered. The Amurian leaves are essentially similar morphologically, and the leaf mats also contains seeds externally like those from the Canadian locality, but preserved as compression and cleared for microscopic studies. There are also floral and fruit remains impressed upon the leaves and probably in situ (Fig. 8A-D). The pistillate structures are supported by a funnel-shaped bract (spathe), actinomorphic, with a concave ovary containing a dense mass of ovules, developing into a capsulate fruit with persistent (staminodal?) appendages. The seeds are straight or slightly curved, with micropyle and chalaza nearly in line or the chalazal cap ventrally displaced and the hilum scar at a variable distance form it. The flower/fruit morphology suggests general affinities with the Alismatales - Arales plexus exhibiting some characteristic features of the Hydrocharitaceae (such as flexible location of the hilum relative to chalaza and the papillose inner integument. The plant is therefore "synthetic", sharing characters of at least two and probably more recent groups of aquatic plants.

A rich dinosaur locality in the coarser sandy deposits up the section may confirm association of late dinosaur communities with a highly productive aquatic vegetation previously suggested on evidence of abundant lemnoid seeds from the Maastrichtian dinosaur beds of Mongolia (Krassilov \& Makulbekov 1995).

\section{Conclusion}

Continuity of the Late Cretaceous-Paleogene Trochodendroides flora of eastern Asia and western North America is confirmed by morphological comparison of its dominant components, the platanoid and trochodendrocarpoid morphotypes, as well as the wetland (aquatic) plants. Species-level analysis shows patterns of variation, sometimes parallel in representatives of unrelated groups (e.g., Mesocyparis rosanovii $-M$. beringiana $-M$. borealis and Platimeliphyllum valentinii $-P$. palanense $-P$. sp. from 

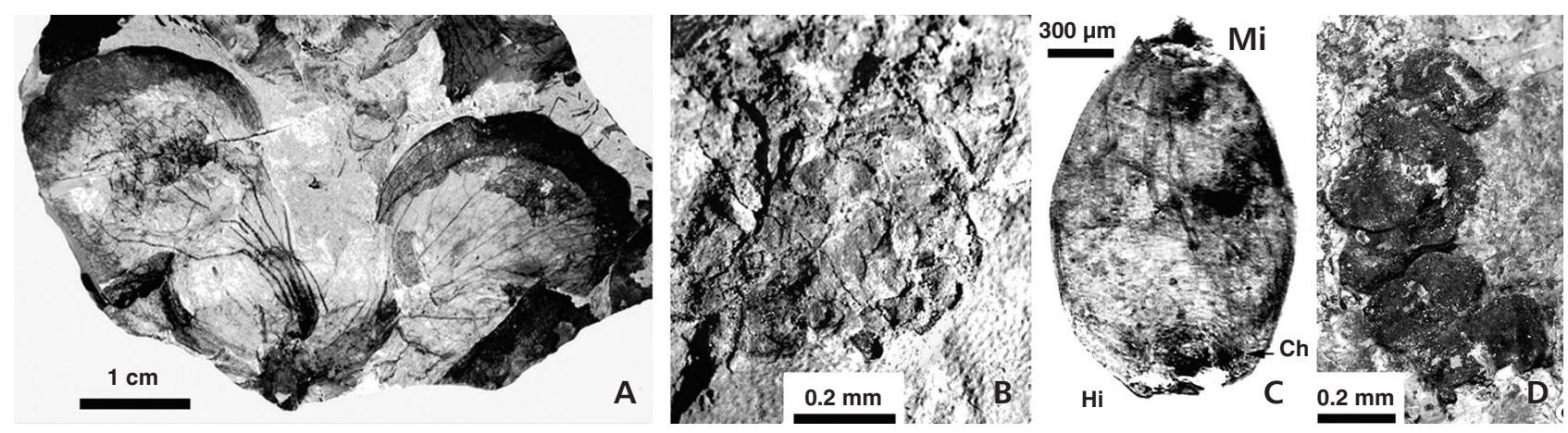

Figure 8. Cobbania corrugata (Lesq.) Stockey, Rothwell \& Johnson (alismatalean-aralean plexus, see text) from the Campanian Kundur Formation, Kundur locality, Amur Province, Russia. • A - leaf rosette, GIN 4867 No.K16/3-23. • B - fruit head impressed on a leaf, GIN 4867 No. K16/8-120. - $\mathrm{C}$ - cleared seed showing micropyle (Mi), chalaza (Ch) and hilum scar (Hi). • D - fruit with seed compressions, GIN 4687 No. K16/3-54.

Fushun and Clarno), for which an Asiatic centre of speciation is postulated, with a polymorphic resident species giving rise, through monomorphic marginal populations, to a diversity of derived forms, some of which crossed the Bering Land Bridge. Alternatively, local species might have been differentiated over a broad trans-Beringian ancestral range, as in Ditaxocladus.

At the same time, morphological disparity of taxonomically related Asiatic and American forms apparently correlates with their geological age. In the trochodendrocarpoid plants, appearing on both flanks of Beringia in the Turonian already, a generic level divergence is suggested by dissimilar inflorescence structures in Asiatic Trochodendrocarpus type and American Joffrea. This situation indicates periodic, rather than permanent, exchanges through geological times. Major transBeringian migrations might have coincided with global warming trends in the mid-Cenomanian, Campanian and the late Paleocene, when more species of mid-latitude origin might have ascended to high latitudes. Three stages in evolution of aquatic vegetation supposedly correspond to these major trans-Beringian migration events.

The role of aquatic vegetation as a forage for dinosaurs (Krassilov 1981, Krassilov \& Makulbekov 1995) increased with diversity of aquatic plants through the Late Cretaceous. The abundant productivity of aroid and alismatoid monocots might have sustained trans-Beringian migrations of high latitude dinosaur faunas that in their turn propagated aquatic vegetation that was reduced concomitantly with their extinction. Such aquatic dominants as Cobbania might not survive the boundary event, but the deciduous trochodendrocarpoids reached their optimal development in the early Paleocene, thus defying the currently popular notion of catastrophic decimation of terrestrial plant cover at the Cretaceous-Tertiary boundary. Rather, their continuous evolution across the boundary is evidence of a spreading temperization that inflicted a more conspicuous floristic change down the latitudes occupied by subtropical vegetation during the Cretaceous, than in the temperate realm.

\section{Systematic Paleobotany}

Order Coniferales

Family Cupressaceae Gray, 1821

Subfamily Cupressoideae Rich ex Sweet, 1826

\section{Genus Ditaxocladus Guo \& Sun, 1984}

\section{Ditaxocladus kivdensis Kodrul sp. nov.} Figures 9A-I, 10A-E

Holotype. - A specimen GIN 4867 no. PK1-627 (counterpart of same specimen - GIN 4867 no. PK1-625), Geological Institute, RAS, Moscow, Figure 10A.

Type horizon and locality. - Tsagayan Formation, Kivda beds, Paleocene; Progress locality, $18 \mathrm{~km}$ south-east of Raichikhinsk Town, Amur Province, Russia (49² $42^{\prime} 23.6^{\prime \prime} \mathrm{N}$, $129^{\circ} 37^{\prime} 28.0^{\prime \prime} \mathrm{E}$; WGS 84).

Etymology. - Name derived from the Kivda River.

Material. - 30 specimens of leafy branches and seed cones from the lower part of the Upper Tsagayan Member Tsagayan Formation, Mount Belaya locality $\left(49^{\circ} 36^{\prime} 06.6^{\prime \prime} \mathrm{N}\right.$, $129^{\circ} 36^{\prime} 05.2^{\prime \prime} \mathrm{E}$ ); about 20 specimens of leafy twigs and seed cones and single specimen with attached pollen cones from Kivda Member (uppermost Tsagayan Formation) in open quarries of the Raichikhinsk brown coal field at the Progress (49 $\left.42^{\prime} 23.6^{\prime \prime} \mathrm{N}, 129^{\circ} 37^{\prime} 28.0^{\prime \prime} \mathrm{E}\right)$ and Pioneer $\left(49^{\circ} 39^{\prime} 13.7^{\prime \prime} \mathrm{N}, 129^{\circ} 33^{\prime} 47.0^{\prime \prime} \mathrm{E}\right)$ localities, and one specimen of large leafy branch from the upper part of the Upper Tsagayan Member at the Pioneer locality $\left(49^{\circ} 40^{\prime} 53.9^{\prime \prime} \mathrm{N}\right.$, $\left.129^{\circ} 34^{\prime} 00.1^{\prime \prime} \mathrm{E}\right)$, ca 6-7 m below the base of the Kivda Member.

Diagnosis. - Foliage branching plagiotropic, bipinnate, opposite. Branches and branchlets arising in the axils of lateral leaves, obliquely spreading. Leaves persistent, scale-like, 

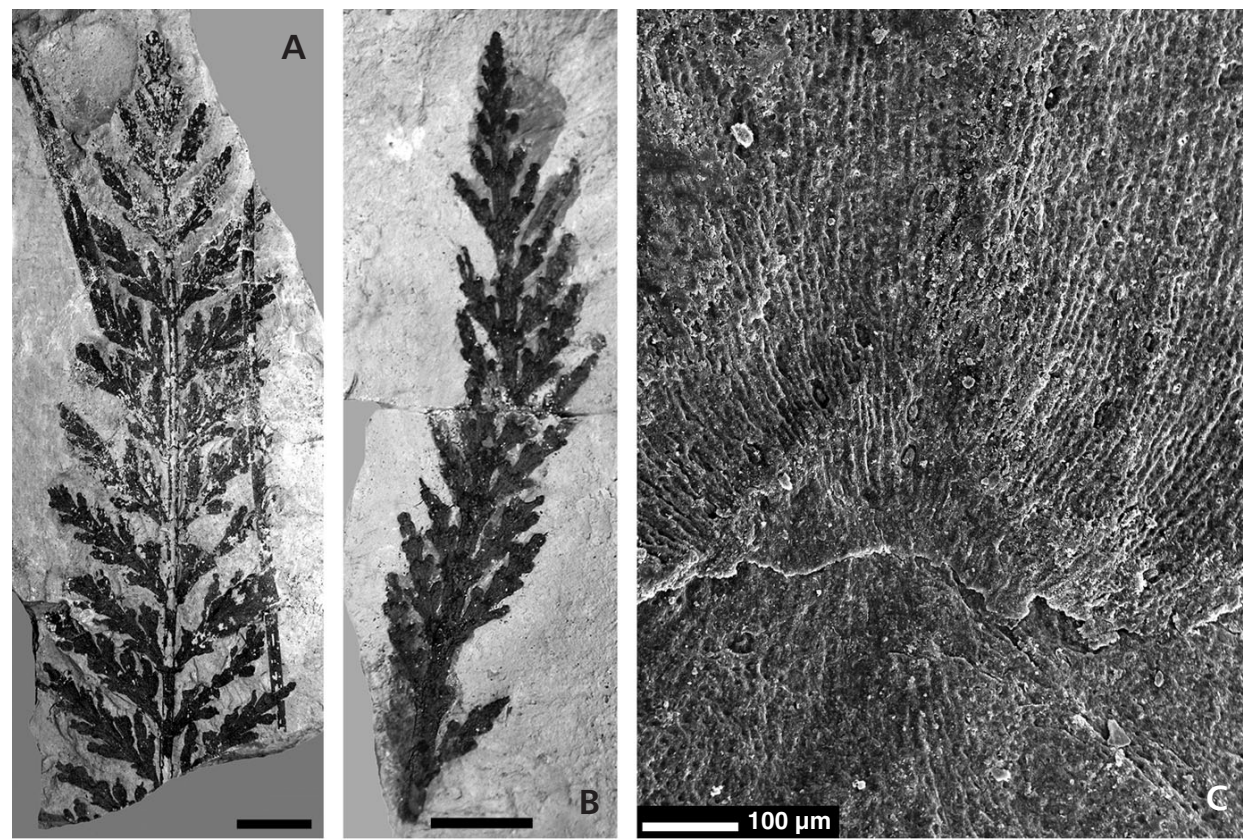

Figure 9. Ditaxocladus kivdensis Kodrul sp. nov. (Cupressaceae) from the Paleocene of Amur Province, Russia. • A, B, I- opposite branching in vegetative shoots GIN 4867 No. PK1-15, No. BG742, No. PN1-89. - $\mathrm{C}$ - mineral film with impression of epidermal structures. GIN 4867 No. PN1-89. • D, F - microstrobili. GIN 4867 No. PK1-636. • E, H - pollen grains. GIN 4867 No. PK1-636, light microscope, SEM. $\bullet$ G - leafy branch with terminal pollen cones. GIN 4867 No. PK1-636. Scale bar: D, F = $2 \mathrm{~mm}$; = $5 \mathrm{~mm}$; A, B, G = $10 \mathrm{~mm}$.
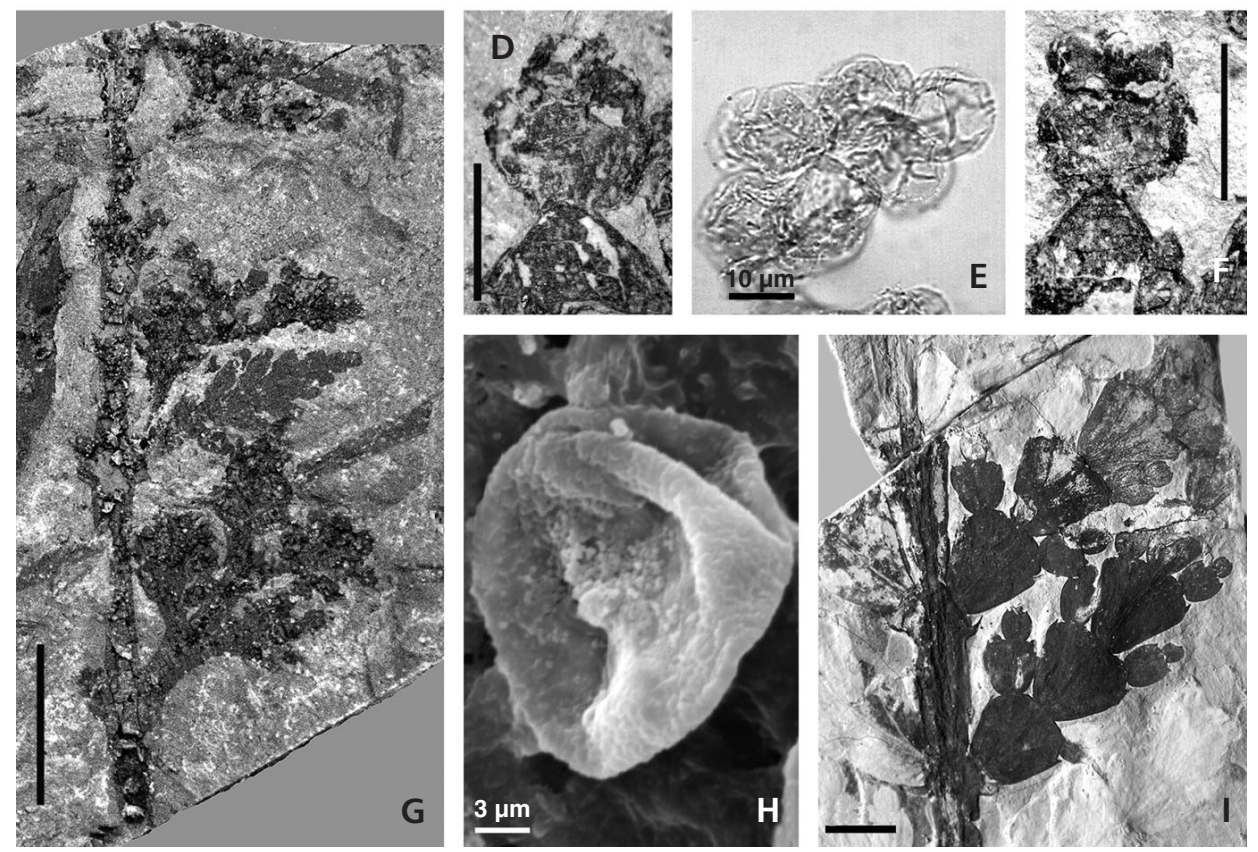

distinctly flattened, in pseudowhorls of four, dimorphic. Facial and lateral leaves approximately equal in length. Facial leaves obovate to oblanceolate, adaxial surface flatly appressed to the shoot, length to width ratio $2: 1$ to $8: 1$; apex acuminate, rarely mucronate, thickened; apex overlaps the base of following facial leaf. Lateral leaves oblong, folded, decurrent, bilaterally flattened, clasping facial leaves or subtending branches of higher order, length to width ratio $2: 1$ to $11: 1$; apex acute or acuminate, appressed or occasionally spreading. Leaves amphistomatic, stomata in irregular rows mostly near the base and the apex of leaves. Pollen cones subglobose, up to $2.2 \mathrm{~mm}$ long, $2 \mathrm{~mm}$ in diameter, terminal on ultimate branchlets, solitary, consisting of three to four decussate pairs of microsporophylls; laminate part of microsporophylls deltoid. Sporangia abaxial, two at base of lamina, obovate, $0.3 \mathrm{~mm}$ long, $0.2 \mathrm{~mm}$ in diameter. Pollen $10-15 \mu \mathrm{m}$ in diameter, spherical to slightly elliptical, irregularly gemmate. Seed cones pendulous, oblong, 9-11 mm long, $6.5-8 \mathrm{~mm}$ in diameter, borne on leafy branchlets 3-6.5 mm long, 1.5-2 $\mathrm{mm}$ in diameter in opposite distichous pairs over fertile axes. Cone scales 6-8 in three or four decussate pairs, woody, valvate at cone base, higher peltate, shield rounded-rhomboid with small subapical, rarely nearly central, mucronate umbo and low transverse ridge. 
Figure 10. Seed cones of Ditaxocladus kivdensis Kodrul sp. nov. from the Paleocene of Amur Province, Russia. $・ A-$ cones arranged in opposite distichous pairs, seldom on one side, over the fertile zone, holotype GIN 4867 No. PK1-627. - B - detail of holotype GIN 4867 No. PK1-627. • C, D - pendulous seed cones. UF 18650-30326, 18650-30325. • E -oblong seed cone with rounded-rhomboid peltae showing small subapical mucronate umbo, detail of UF 18650-30325. Scale bar: B, E $=5 \mathrm{~mm}, \mathrm{~A}, \mathrm{C}, \mathrm{D}=$ $10 \mathrm{~mm}$.
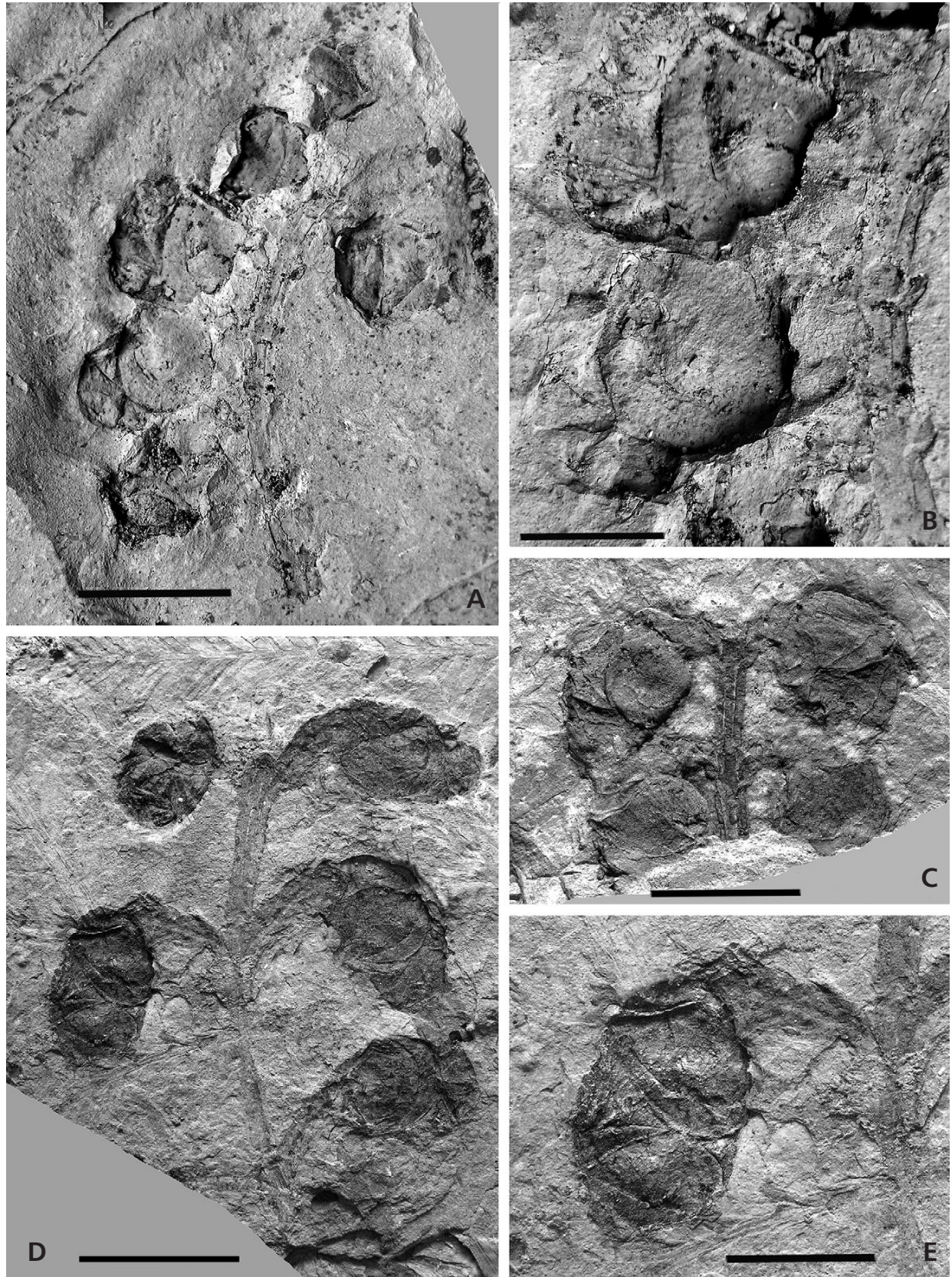

Description. - The foliage of Ditaxocladus kivdensis sp. nov. is plagiotropic, flattened in a single plane. The twigs are pinnately arranged, decreasing gradually, precisely oppositely branched from the axils of lateral leaves (Fig. 9A, B, G, I). Most shoot remains bear branches of three orders. The major axes $2.5-11 \mathrm{~cm}$ long bear up to 16 branches 1-25 mm long, which diverge from midline at angles of $30-50^{\circ}, 1.5-17 \mathrm{~mm}$ apart. The ultimate branchlets are up to $10 \mathrm{~mm}$ long and arise at angles of $25-40^{\circ}, 2-6 \mathrm{~mm}$ apart. The leaves of vegetative shoots are scaly, decussate, in pseudowhorls of four, flattened, and strongly dimorphic. The lateral leaves are shorter than facial or nearly equal. The facial leaves are narrow - oblanceolate on the major axes to obovate on penultimate and ultimate twigs with adaxial surface flatly appressed to the shoot, length of facial leaves range within $0.5-15 \mathrm{~mm}$, width $0.4-2.5 \mathrm{~mm}$, absolute size of leaves decreases on branchlets of higher orders. The apices are acuminate or truncate with mucronate tip, thickened; the apex overlaps slightly the base of following facial leaf. The lateral leaves are $0.4-14.5 \mathrm{~mm}$ long and $0.5-3.4 \mathrm{~mm}$ wide, longitudinally folded and appressed, partly overlapped associated facial leaves, with a decurrent leaf cushion and acute or acuminate apex, commonly appressed to adjacent facial leaf or rarely free (Fig. 9I). The leaves are amphistomatic, stomata form short longitudinal rows mostly near the base of leaves and are bordered by 

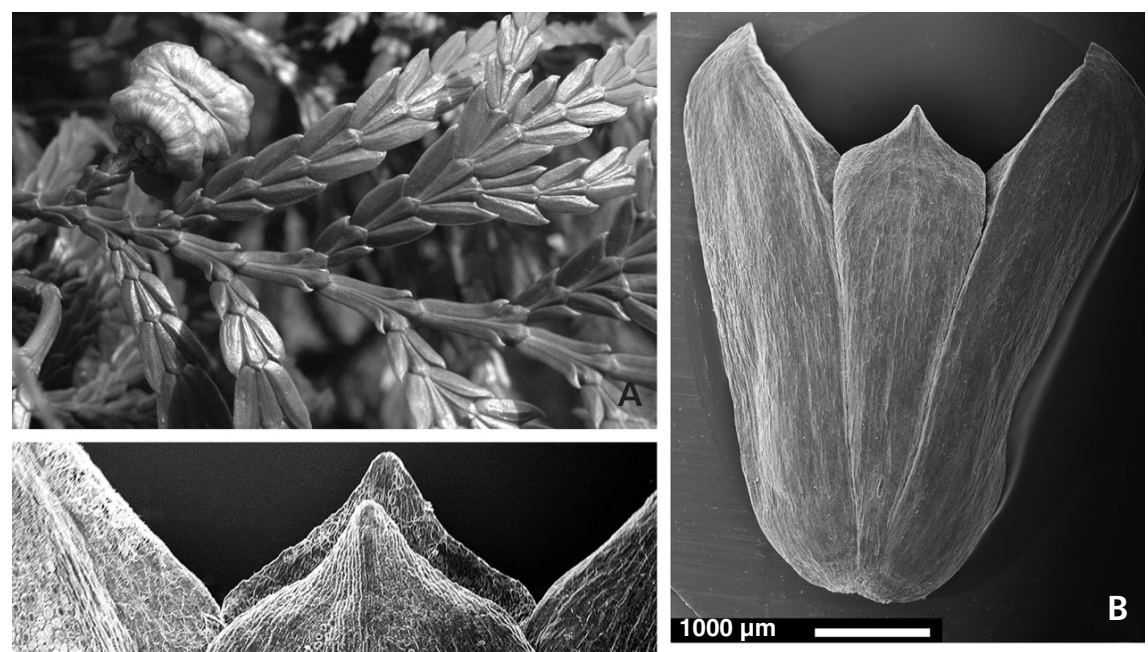

Figure 11. Fokienia hodginsii (Dunn) Henry \& Thomas. • A - leafy branch with a solitary seed cone terminating a short branchlet (at left). - B, C - leaf pseudowhorls, adaxial (B) and abaxial (C) side of leaf. $\bullet$ D - microsporophyll with four adaxial sporangia.
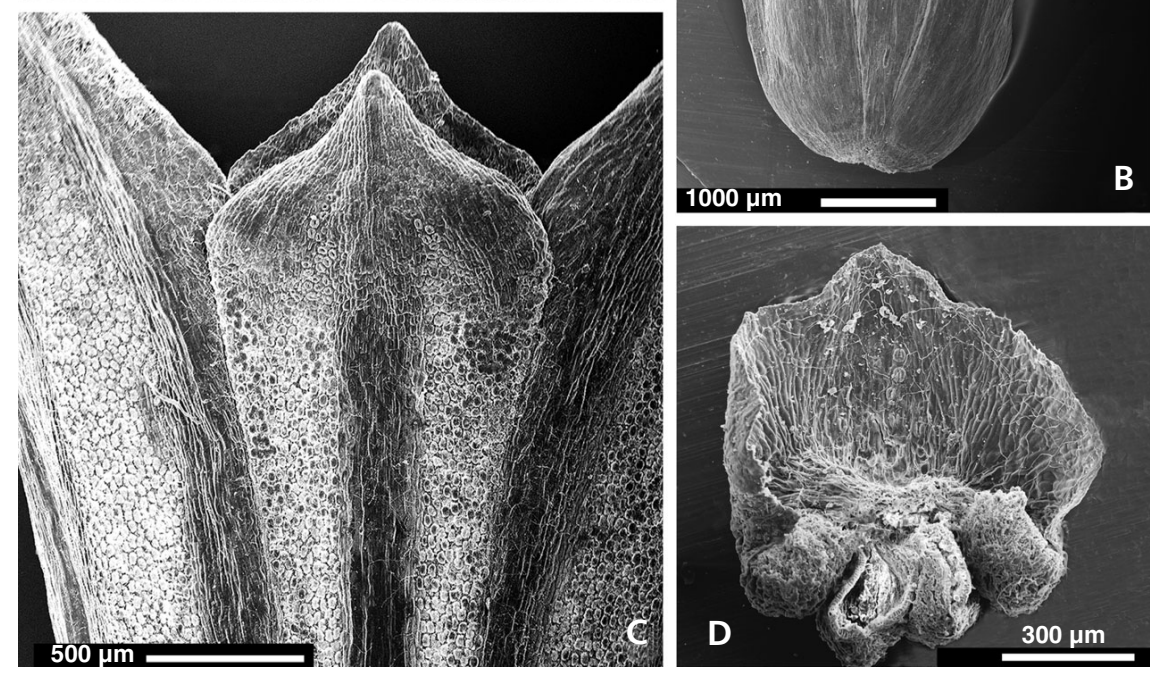

a Florin ring, stomatal apertures are oriented parallel or slightly obliquely to the midline of leaves. The ordinary epidermal cells are straight walled, usually quadrangular and isodiametric, becoming narrowly quadrangular at the base of leaves (Fig. 9C). Pollen cones are small, probably immature, solitary, subglobose, up to $2.2 \mathrm{~mm}$ long, $2 \mathrm{~mm}$ in diameter, terminate ultimate branchlets, which are aggregated in fertile zones of the penultimate shoots (Fig. 2D, F, G). The microsporophylls are arranged on the cone axis decussately in three or four pairs; the laminate part is deltoid in shape about as wide as long with tapered apex. They bear two abaxial sporangia at the base of lamina. Sporangia are obovate, $0.3 \mathrm{~mm}$ long, $0.2 \mathrm{~mm}$ in diameter. The pollen grains are $10-15 \mu \mathrm{m}$ in diameter, spherical to slightly elliptical with small gemmae irregularly distributed on the pollen surface (Fig. 9E, H). The seed cones are pendulous, oblong, 9.0-11.0 mm long, 6.5-8.0 $\mathrm{mm}$ in diameter, arranged in opposite distichous pairs along fertile zone of axis, sometimes cones are developed only on one side of axis (Fig. 3A-E). The cones borne on stout, densely leafy branchlets 3-6.5 $\mathrm{mm}$ long, $1.5-2 \mathrm{~mm}$ in diameter, branching from the axils of lateral leaves at a range 5-15 $\mathrm{mm}$. Up to five cone pairs are known for Amurian Ditaxocladus. There are 6-8 cone scales arranged in three or four decussate pairs and closely appressed to each other. The cone scales are woody, small at the base and apex of cones, val- vate at cone base, higher peltate, distal shields are rounded-rhomboid or rhomboid with low transverse ridge and small mucronate umbo positioned ca. one third of the distance from the apex to the base of scale or rare nearly centre of scale.

Remarks. - The vegetative shoots of this conifer with bipinnate opposite branching and flattened phylloclade-like foliage, have been first described as Androvettia catenulata Bell (1949). Later Brown (1962) assigned this species to Fokienia catenulata (Bell) R.W. Brown based on new material from the Paleocene Fort Union and Evanston formations in Montana and Wyoming. The latter name was accepted by Chandrasekharam (1974) for similar shoots from the Paleocene of Alberta, Canada. From the Cretaceous and Paleogene of Russian North East, Far East and Kazakhstan, such shoots were described as Androvettia catenulata (Krassilov 1976) or Libocedrus catenulata (Bell) Kryshtofovich (Kryshtofovich \& Baikovskaya 1966, Sveshnikova 1967, Romanova 1975, Lebedev 1987, Samylina 1988). The frond-like foliage with opposite branching and unattached roundish bodies interpreted as cone scales of the same plant were described from the Paleocene of Altai piedmonts, Xinjiang Uygur Autonomous Region, northwestern China as a new genus and species Ditaxocladus planiphyllus Guo \& Sun (Guo et al. 1984). The roundish 
bodies have been later recognized as fruits of the genus Nordenskioldia (Crane et al. 1991). In the same contribution, the authors (Guo et al. 1984) noted that Ditaxocladus foliage resembles Androvettia catenulata, but differs in the presence of scaly leaves. They also compared Ditaxocladus to extant Fokienia Henry \& Thomas.

Subsequently, subglobose seed cones attached to Ditaxocladus twigs were collected from type locality of Ditaxocladus planiphyllus in Xinjiang Uygur Region (Kvaček et al. 2000). Nearly identical cupressaceous leafy twigs with attached seed cones and isolated pollen cones were described from the Paleocene of Saskatchewan and Alberta, Canada as Fokienia ravenscragensis McIver \& Basinger (McIver \& Basinger 1990, McIver 1992). The assignment to the extant genus was based on similarity of the seed cone structure. At the same time, a morphological genus Fokieniopsis McIver \& Basinger was erected for the vegetative shoot remains, including Fokienia catenulata and Ditaxocladus planiphyllus.

However, in a later study, the type material of Androvettia from the Cretaceous of eastern North America was re-interpreted as phyllocades of supposed cheirolepidiaceous affinities (Hueber \& Watson 1988). The earliest generic name Androvettia Hollick \& Jeffrey (1909) applied to such shoots is unacceptable for the cupressaceous fossils under description. It was concluded from the study of shoot development and morphology in three species of Androvettia from the Upper Cretaceous of the eastern United States (A. statenensis Hollick \& Jeffrey, A. carolinensis Berry and A. elegans Berry) that this genus is monotypic and probably belongs to the family Cheirolepidiaceae (Hueber \& Watson 1988). The branching system of Androvettia statenensis is a typical phylloclade with the margins appearing lobed and serrate. The stomata are scattered over the whole leaf surface. Prominent papillae are developed around stomatal apertures and on ordinary epidermal cells. In contrast, the leafy shoots of $A$. catenulata Bell (1949), from the Paleocene of Canada are typically cupressaceous. This species was assigned by Brown (1962) to extant genus Fokienia.

Living Fokienia (Fig. 11A-D) is a monotypic genus endemic in South China, Laos, and Vietnam (Farjon 2005). The shoots and foliage of Fokienia are similar to those of Ditaxocladus. However, the ultimate branchlets of the extant plant alternate (Fig. 11A) while in the fossil species they are strictly opposite. The leaves of Fokienia are decussate, in pseudowhorls of four, convex-concave, hypostomatic with stomata in broad bands on the underside of the leaves, on the upper side the stomata are rare or lacking (Fig. 11B, C). The lateral leaves of Fokienia are longer than or nearly equal to the facials. The leaves of Asian and North American Ditaxocladus are biconvex, amphistomatic, with stomata in short irregular rows mostly near the base of leaves on either side of the branch, the facial leaves are longer than the lateral. The seed cones of Fokienia are solitary, terminal on very short leafy branchlets, globose to subglobose with 10-16 cuneate-peltate scales (Fig. 11A) whereas those of Ditaxocladus are arranged in several opposite distichous pairs on fertile axis, globose to ovoid or oblong with 3 to 4 pairs of valvatepeltate cone scales. We conclude that the cupressaceous fossils under consideration are not assignable to the extant genus Fokienia on account of both foliage and seed cone morphology and the leaf epidermal structures.

The extant genus Libocedrus differs from Ditaxocladus in the morphology of seed cones mainly, with the cone scales born in two decussate pairs. There are also epidermal distinctions, the stomata of Libocedrus being predominantly arranged in conspicuous bands on the underside of the phylloclade branchlets (Farjon 2005).

The extant genera standing for comparison differ in having solitary, rather than paired, seed cones (Fokienia) or 4-scale cones (Libocedrus). The priority of Ditaxocladus Guo \& Sun over Fokieniopsis McIver \& Basinger has been recognized by Guo et al. (unpublished manuscript). The validity of Ditaxocladus was confirmed by Kvaček (2008).

At the species level, the Amurian Ditaxocladus differs from its congeners the Canadian species (McIver \& Basinger 1990; McIver 1992) in the denser penultimate and ultimate branches and in morphology and dimensions of the reproductive structures. In D. kivdensis microstrobili are terminal on the ultimate branchlets (only shed microstrobili of Ditaxocladus were heretofore known). The Amurian pollen cones are subglobose, up to $2.2 \times 2 \mathrm{~mm}$ in size, composed of 3-4 pairs of microsporophylls each with two sporangia. The Canadian microstrobili are twice as long consisting of a greater number of microsporophylls, the pollen grains are a larger as well $(25-30 \mu \mathrm{m}$ and $10-15 \mu \mathrm{m}$ respectively). The seed cones of $D$. kivdensis are pendulous, loose on fertile branches, oblong, up to $8 \times 11 \mathrm{~mm}$, with $6-8$ scales per cone, peltae of the cone scales are rounded-rhomboid with small subapical, seldom nearly central, mucronate umbo and a low transverse ridge. In the Canadian specimens, the seed cones are terminal on erect or horizontal leafy branchlets on fertile axes, about $5 \mathrm{~mm}$ apart, subglobose or ovoid, up to $10 \times 12 \mathrm{~mm}$, with a greater number of cone scales (up to 12). The peltae are narrowly rhomboid with central umbo (McIver \& Basinger 1990, McIver 1992, Guo et al. submitted). The Chinese conifer differs from the Amurian plant in somewhat smaller globose to subglobose seed cones. The peltae of cone scales are rhomboid with central umbo and a prominent transverse ridge (Guo et al., unpublished manuscript).

Occurrence. - Eastern Asia, Amur Province, Russia, Zeya - Bureya Basin, Tsagayan Formation, Paleocene. 


\section{Acknowledgements}

We acknowledge the courtesy of L. Golovneva, Botanical Institute, Russian Academy of Sciences (RAS), Jin Jianhua and Liao Wenbo, School of Life Sciences, Sun Yat-sen University, Guangzhou, China, K. Zaytseva, Botanical Garden of the Moscow State University, and M. Tekleva, Paleontological Institute, RAS for providing paleobotanical and extant material for this study. We are grateful to S. Manchester and Z. Kvaček for their kind permission to refer to their unpublished material on Ditaxocladus and Platimeliphyllum. We thank M. Collinson, Z. Kvaček and the reviewers for their comments and corrections. This research was supported by the Leading Scientific Schools (No. 4185.2008.5), the Russian Foundation for Basic Research, project. 09-05-00107, 07-04-92127-GFEN and 07-04-00687, and the Program 15 of the Presidium of the RAS. V.A. Krassilov acknowledges the support by the German-Israeli Foundation for Science Research and Development (1-888-159.8/2005).

\section{References}

ABRAMOVA, L.N. 1983. Late Cretaceous flora of Khatanga River Basin, 118-127. In BONDAREV, V.I. (ed) Paleontological basis of the Paleozoic and Mezocoic deposits differentiation of the USSR Arctic regions. Sevmorgeo, Leningrad. [in Russian]

AKHMETIEV, M.A., KEZINA, T.V., KodRUL, T.M. \& MANCHESTER, S.R. 2002. Stratigraphy and flora of the Cretaceous-Paleogene boundary layers in the southeast part of the Zeya-Bureya sedimentary basin, 275-315. In AKHMETIEV, M.A., DOLUdEnKo, M.P., HeRMAN, A.B. \& IGNATIEV, I.A. (eds) Special volume dedicated to the memory of the Corresponding member of the USSR Academy of Sciences, Professor Vsevolod Andreevich Vakhrameev (to the $90^{\text {th }}$ anniversary of his birth). GEOS, Moscow. [in Russian].

BELL, W.A. 1949. Uppermost Cretaceous and Paleocene floras of western Alberta. Bulletin of the Geological Survey of Canada $13,1-231$.

BERRY, E.W. 1911. Systematic paleontology, Lower Cretaceous: fossil plants. Angiospermae, 214- 508. In CLARK, W.B. (ed.) Lower Cretaceous. Maryland Geological Survey, Baltimore, Maryland.

BERRY, E.W. 1935. A preliminary contribution to the floras of the Whitemud and Ravenscrag formations. Geological Survey of Canada, Department of Mines, Memoir 182, 1-107.

BROWN, R.W. 1939. Fossil leaves, fruits and seeds of Cercidiphyllum. Journal of Paleontology 13, 485-499.

BROWN, R.W. 1962. Paleocene flora of the Rocky Mountains and Great Plains. U.S. Geological Survey Professional Paper 375, $1-119$.

BudANTSEV, L.Y. 1996. The new species of Macginitiea (Platanaceae) from the Eocene of western Kamchatka. Botanical Journal 81(9), 67-73 [in Russian].

BugdaEVA, E.V., MARKEVICH, V.S., SOROKIN, A.P. \& BOLOTSKY, Y.L. 2001. Chapter 2. Stratigraphy, 25-43. In BUGDAEVA, E.V. (ed.) Flora and dinosaurs at the CretaceousPaleogene boundary of the Zeya-Bureya Basin. Dalnauka, Vladivostok [in Russian].
Bugdaeva, E.V., Volynets, Y.B., Golozubov, V.V., MaRKEVICH, V.S. \& AMELCHENKO, G.L. 2006. Flora and geological events of the Mid-Cretaceous time (Alchan Basin, Ptimorye). 205 pp. Dalnauka, Vladivostok.

CHANDRASEKHARAM, A. 1974. Megafossil flora from the Genesee locality, Alberta, Canada. Palaeontographica, Abteilung B $147,1-47$.

CRANe, P.R., MANCheSTER, S.R. \& DilCheR, D.L. 1991. Reproductive and vegetative structure of Nordenskioldia (Trochodendraceae), a vesselless dicotyledon from the early Tertiary of the Northern Hemisphere. American Journal of Botany 78, 1311-1334. DOI 10.2307/2445271

CRAnE, P.R. \& StOckey, R.A. 1985. Growth and reproductive biology of Joffrea speirsii gen. et sp. nov., a Cercidiphyllumlike plant from the Late Paleocene of Alberta, Canada. Canadian Journal of Botany 63(2), 340-364.

DORF, E. 1942. Upper Cretaceous floras of the Rocky Mountain region. II. Flora of the Lance Formation at its type locality, Niobrara County, Wyoming. Carnegie Institution of Washington Publication 508, 83-168.

ENDRESS, P.K. 1993. Trochodendraceae, 599-602. In KUBITZKI, K., ROHWER, J.G. \& BITTRICH, V. (eds) The families and genera of vascular plants. Vol. 2. Springer, Berlin

FARJON, A. 2005. A monograph of Cupressaceae and Sciadopitys. 643 pp. Royal Botanic Gardens, Kew.

GolovneVA, L.B. 1987. A new species of the genus Haemanthophyllum from the Rarytkin series of Koryak Upland. Botanical Journal 72, 1127-1131. [in Russian]

GolovneVA, L.B. 1994. Maastrichtian - Danian floras of the Koryak Upland. 148 pp. Botanical Institute RAS, St. Petersburg.

GolovneVA, L.B. 1997. Morphology, systematics and distribution of the genus Haemanthophyllum in the Paleogene floras of the Northern Hemisphere. Paleontological Journal 31, 197-207.

GolovnEVA, L.B. 2000. Aquatic plant communities at the Cretaceous-Palaeogene boundary in north-eastern Russia. Acta Palaeobotanica 40, 139-151.

GolovnEVA, L.B. 2005. Phytostratigraphy and evolution of the Albian-Campanian flora in the Siberian region, 177-197. In ARKAdiEV, V.V. \& Prozorovsky, V.A. (eds) The Cretaceous system of Russia: the problems of stratigraphy and paleogeography. St. Petersburg State University, St. Petersburg. [in Russian]

GolovNEVA, L.B. 2006. Alasia, gen. nov. - male inflorescences, associated with Trochodendroides leaves (Cercidiphyllaceae). Botanical Journal 91(12), 1898-1906.

GolovneVA, L.B \& KRASSILOV, V.A. 2001. New genus of heterosporous ferns of the order Heroleandrales from the Lower Cretaceous of Kazakhstan. Paleontological Journal 3, 108-112. [in Russian]

GuO, S.-X., SUN, Z.-H., LI, H.-M. \& DOU, Y.-W. 1984. Paleocene megafossil flora from Altai of Xinjiang. Bulletin of the Nanjing Institute of Geology \& Palaeontology, 8, 119-146. [in Chinese]

HICKEY, L.J. 2001. On the nomenclatural status of the morphogenera Quereuxia and Trapago. Taxon 50(4), 1119-1124. DOI 10.2307/1224729

Herman, A.B., Akhmetiev, M.A., Kodrul, T.M., Moi- 
SEEVA, M.G. \& YAKOVLEVA, A.I. 2009. Flora development in Northeastern Asia and Northern Alaska during the Cretaceous-Paleogene transitional epoch. Stratigraphy and Geological Correlation 17(1), 79-97. DOI $10.1134 / \mathrm{S} 0869593809010079$

HoLLICK, A. \& JEFFREY, E.C. 1909. Studies of Cretaceous remains from Kreischerville, New York. Memoirs of the New York Botanical Garden 3, 1-138.

HSÜ, J. 1983. Late Cretaceous and Cenozoic vegetation in China, emphasizing their connection with North America. Annals of the Missouri Botanical Garden 70, 490-508. DOI $10.2307 / 2992084$

HuEBER, F.M. \& WATSON, J. 1988. The unusual Upper Cretaceous conifer Androvettia from eastern U.S.A. Botanical Journal of the Linnean Society 98, 117-133.

DOI $10.1111 / \mathrm{j} .1095-8339.1988 . t b 01699 . x$

JOHNSON, K.R. 1985. The Puercan flora and paleoenvironments of the Hunt Creek Sandstone Member of the Fort Union Formation, northern Bighorn Basin, Park County, Wyoming and Carbon County, Montana. 204 pp. Master thesis, University of Pennsylvania, Philadelphia, USA.

JOHNSON, K.R. 2002. Megaflora of the Hell Creek and lower Fort Union formations in the western Dakotas: vegetational response to climate change, the Cretaceous-Tertiary boundary event, and rapid marine transgression. Geological Society of America Special Paper 361, 329-391.

KNOWLTON, F.H. 1917. Flora of the Fruitland and Kirtland formations. U.S. Geological Survey Professional Paper 98S, 327-355.

KodRUL, T.M. \& MASLOVA, N.P. 2007. A new species of the genus Platimeliphyllum N. Maslova from the Paleocene of the Amur Region, Russia. Paleontological Journal 41(11), 1-5. DOI 10.1134/S003103010711010X

KoDRUL, T.M., TeKLEVA, M. \& KRAssilov, V.A. 2006. A new conifer species, Mesocyparis rosanovii sp. nov. (Cupressaceae, Coniferales), and trans-Beringian floristic connections. Paleontological Journal 40(3), 328-338. DOI $10.1134 / \mathrm{S} 0031030106030142$

KRASSILOV, V.A. 1973. Cuticular structures of Cretaceous angiosperms from the Far East of the USSR. Palaeontographica, Abteilung B 142, 105-116.

KRASSILOV, V.A. 1976. Tsagayan flora of Amur Province. 92 pp. Nauka, Moscow. [in Russian]

KrassiLOV, V.A. 1979. Cretaceous flora of Sakhalin. 182 pp. Nauka, Moscow. [in Russian]

KRASSILOV, V.A. 1981. Changes of Mezozoic vegetation and the extinction of dinosaurs. Palaeogeography, Palaeoclimatology, Palaeoecology 34, 207-224.

DOI 10.1016/0031-0182(81)90065-1

KRASSILOV, V.A. 1989. Vavilov's species concept and evolution of variation. Evolutionary Theory 9, 37-44.

Krassilov, V.A. \& GolovneVA, L.B. 1999. A new heterosporous plant from the Cretaceous of West Siberia. Review of Palaeobotany and Palynology 105, 75-84.

DOI 10.1016/S0034-6667(98)00064-5

KRASSILOV, V.A. \& KodRUL, T.M. 2008. In situ pollen of Alasia, a supposed staminate inflorescence of Trochodendroides plant. Acta Musei Nationalis Pragae, Series B 64(2-4), 115-124.
Krassilov, V.A., Lewy, Z., NeVo, E. \& SilantieVA, N. 2005. Turonian flora of Southern Negev, Israel. 252 pp. Pensoft, Sophia.

Krassilov, V.A. \& MAKUlBeKOV, N.M. 1995. Maastrichtian aquatic plants from Mongolia. Paleontological Journal 29(2), $119-140$.

KRYSHTOFOVICH, A.N. 1935. New data on Cretaceous flora of North America in connection with floras of Far East. Year-book of All-Russian Paleontological Society 10, 89-103. [in Russian]

KRYShTOFOVICH, A.N. \& BAIKOVSKAYA, T.N. 1966. Upper Cretaceous Tsagayan flora of Amur Province, 184-320. In KRYSHTOFOVICH, A.N. Selected works Vol. 3. Nauka, Moscow. [in Russian]

KVAČEK, Z. 1995. Limnobiophyllum Krassilov - a fossil link between the Araceae and the Lemnaceae. Aquatic Botany 50, 49-61. DOI 10.1016/0304-3770(94)00442-O

KVAČEK, Z. 2008. The role of types in palaeobotanical nomenclature. Acta Musei nationalis Pragae, Series B 64(2-4), 89-96.

KVAČEK, Z., MANCHESTER, S.R. \& SCHORN, H.E. 2000. Cone, seeds and foliage of Tetraclinis salicornioides (Cupressaceae) from the Oligocene and Miocene of western North America: a geographic extension of the European Tertiary species. International Journal of Plant Sciences 161, 331-344.

DOI $10.1086 / 314245$

LEBEDEV, E.L. 1987. Stratigraphy and age of Okhotsk-Chukotka volcanic belt. 176 pp. Nauka, Moscow. [in Russian]

MANCHESTER, S.R. 1986. Vegetative and reproductive morphology of an extinct plane tree (Platanaceae) from the Eocene of western North America. Botanical Gazette 14(2), 200-226. DOI $10.1086 / 337587$

MANCHESTER, S.R. 1999. Biogeographical relationships of North American Tertiary floras. Annals of the Missouri Botanical Garden 86(2), 472-522. DOI 10.2307/2666183

MANChester, S.R., CHEN, Z.-D., LU, A.-M. \& UEMURA, K. 2009. Eastern Asian endemic seed plant genera and their paleogeographic history throughout the Northern Hemisphere. Journal of Systematics and Evolution 47(1), 1-42.

DOI 10.1111/j.1759-6831.2009.00001.x

Markevich, V.S., Golovneva, L.B. \& Bugdaeva, E.V. 2005. Stratigraphy and flora of the Kundur Formation (Upper Cretaceous, Amur Region), 160-176. In ARKADIEV, V.V. \& PROZOROVSKY, V.A. (eds) The Cretaceous system of Russia: the problems of stratigraphy and paleogeography. St. Petersburg State University, St. Petersburg. [in Russian]

MASLOVA, N.P. 2002. A new plant of the family Platanaceae from the Early Paleogene reconstructed on the basis of leaves and inflorescences. Paleontological Journal 36(2), 207-218.

MASLOVA, N.P. 2003. Extinct and extant Platanaceae and Hamamelidaceae: morphology, systematics, and phylogeny. Paleontological Journal 37 (Suppl. 5), 467-590.

MCIVER, E.E. 1992. Fossil Fokienia (Cupressaceae) from the Paleocene of Alberta, Canada. Canadian Journal of Botany 70(4), 742-749.

MCIVER, E.E \& AULENBACK, K.R. 1994. Morphology and relationships of Mesocyparis umbonata sp. nov.: fossil Cupressaceae from the Late Cretaceous of Alberta, Canada. Canadian Journal of Botany 72, 273-295. DO] 10.1139/b94-037 
MCIVER, E.E \& BASINGER, J.F. 1987. Mesocyparis borealis gen. et sp. nov.: fossil Cupressaceae from the Early Tertiary of Saskatchewan, Canada. Canadian Journal of Botany 65, 2338-2351. DOI 10.1139/b87-318

MCIVER, E.E \& BASINGER, J.F. 1990. Fossil seed cones of Fokienia (Cupressaceae) from the Paleocene Ravenscrag Formation, Saskatchewan, Canada. Canadian Journal of Botany 68(7), 1609-1618.

PEPPE, D.J., ERICKSON, J.M. \& HICKEY, L.J. 2007. Fossil leaf species from the Fox Hills Formation (Upper Cretaceous: North Dakota, USA) and their paleogeographic significance. Journal of Paleontology 81(3), 550-567. DOI 10.1666/05067.1

PigG, K.B. \& STOCKEY, R.A. 1991. Platanaceous plants from the Paleocene of Alberta, Canada. Review of Palaeobotany and Palynology 70(1/2), 125-146. DOI 10.1016/0034-6667(91)90082-E

RILEY, M.G. \& STOCKEY, R.A. 2004. Cardstonia tolmanii gen. et sp. nov. (Limnocharitaceae) from the Upper Cretaceous of Alberta, Canada. International Journal of Plant Sciences 165, 897-916. DOI $10.1086 / 422127$

RomanovA, E.V. 1975. Representatives of Cupressaceae family from the Upper Cretaceous deposits of Mount Juvankara (Zaissan depression). Botanical Journal 60, 1191-1194. [in Russian]

SAMYLINA, V.A. 1968. Early Cretaceous angiosperms of the Soviet Union based on leaf and fruit remains. Botanical Journal of the Linnean Society 61, 207-218. DOI 10.1111/j.1095-8339.1968.tb00119.x

SAMYLINA, V.A. 1988. Arkagala stratoflora of North East of Asia. 132 pp. Nauka, Leningrad. [in Russian]

STOCKEY, R.A. 2006. The fossil record of basal monocots, 91-106. In Columbus, J.T., Friar, E.A., PORTER, J.M., PRINCE, L.M. \& SIMPSON, M.G. (eds) Monocots: Comparative Biology and Evolution (excluding Poales). Rancho Santa Ana Botanic Garden, Claremont.

Stockey, R.A., Hoffman, G.L. \& Rothwell, G.W. 1997. The fossil monocot Limnobiophyllum scutatum: Resolving the phylogeny of Lemnaceae. American Journal of Botany 84, 355-368. DOI $10.2307 / 2446009$
Stockey, R.A. \& Rothwell, G.W. 1997. The aquatic angiosperm Trapago angulata from the Upper Cretaceous (Maastrichtian) St. Mary River Formation of southern Alberta. International Journal of Plant Sciences 158, 83-94. DOI $10.1086 / 297417$

StOCKEy, R.A., Rothwell, G.W. \& JOHNSON, K.R. 2007. Cobbania corrugata gen. et comb. nov. (Araceae): a floating aquatic monocot from the Upper Cretaceous of western North America. American Journal of Botany 94, 609-624.

DOI 10.3732/ajb.94.4.609

Sun, G., AKhmetiev, M., Golovneva, L., Bugdaeva, E., QUAN, C., KODRUL, T., NishidA, H., SUN, Y., SUN, C., JOHNSON, K. \& DILCHER, D. 2007. Late Cretaceous plants from Jiayin along Heilongjiang River, Northeast China. Courier Forschungsinstitut Senckenberg 258, 75-83.

SVESHNIKOVA, I.N. 1967 Fossil conifers of the Viljui syneclise. Transactions BIN AS USSR, series 8 Palaeobotany 6, 177-204. [in Russian]

TAKHTAJAN, A.L. 1991. Evolutionary trends in flowering plants. 241 pp. Columbia University Press, New York.

TIFFNEY, B.H. 1985. Perspectives on the origin of the floristic similarity between eastern Asia and eastern North America. Journal of the Arnold Arboretum 66, 73-94.

TIFFNEY, B.H. \& MANCHESTER, S.R. 2001. The use of geological and paleontological evidence in evaluating plant phylogeographic hypotheses in the northern hemisphere Tertiary. International Journal of Plant Sciences 162, 3-17.

DOI $10.1086 / 323880$

UpChURCH, G.R., CRAne, P.R. \& Drinnan, A.N. 1994. The megaflora from the Quantico locality (upper Albian), Lower Cretaceous Potomac Group of Virginia. Virginia Museum of Natural History, Memoir 4, 1-57.

WOLFE, J.A. 1975. Some aspects of plant geography of the Northern Hemisphere during the Late Cretaceous and Tertiary Annals of the Missouri Botanical Garden 62, 264-279.

WOLFE, J.A. \& WEHR, W. 1987. Middle Eocene dicotyledonous plants from Republic, northeastern Washington. United States Geological Survey Bulletin 1597, 1-25. 